\title{
molecules
}

ISSN 1420-3049

www.mdpi.com/journal/molecules

Article

\section{Synthesis and Antiplatelet Activity of Antithrombotic Thiourea Compounds: Biological and Structure-Activity Relationship Studies}

André Luiz Lourenço ${ }^{1}$, Max Seidy Saito ${ }^{1}$, Luís Eduardo Gomes Dorneles ${ }^{2}$, Gil Mendes Viana ${ }^{2}$, Plínio Cunha Sathler ${ }^{2}$, Lúcia Cruz de Sequeira Aguiar ${ }^{3}$, Marcelo de Pádula ${ }^{2}$, Thaisa Francielle Souza Domingos ${ }^{2}$, Aline Guerra Manssour Fraga ${ }^{2}$, Carlos Rangel Rodrigues ${ }^{4}$, Valeria Pereira de Sousa ${ }^{2}$, Helena Carla Castro ${ }^{5, *}$ and Lucio Mendes Cabral ${ }^{2, *}$

1 Programa de Pós-graduação em Patologia, Departamento de Patologia, Hospital Universitário Antônio Pedro (HUAP), Universidade Federal Fluminense (UFF), Niterói CEP 24033-900, RJ, Brazil; E-Mails: andrebiouff@gmail.com (A.L.L.); maxsaito@gmail.com (M.S.S.)

2 LabTIF, Faculdade de Farmácia, Universidade Federal do Rio de Janeiro (UFRJ), Rio de Janeiro CEP 21941-902, RJ, Brazil; E-Mails: legdorneles@yahoo.com.br (L.E.G.D.); gmviana@gmail.com (G.M.V.); pliniocs@yahoo.com.br (P.C.S.); marcelo@pharma.ufrj.br (M.P.); thaisadomingos@yahoo.com.br (T.F.S.D.); agmfraga@yahoo.com.br (A.G.M.F.); valeria@pharma.ufrj.br (V.P.S.)

3 Instituto de Química, Universidade Federal do Rio de Janeiro (UFRJ), Rio de Janeiro CEP 21941-909, RJ, Brazil; E-Mail: luciasequeira@yahoo.com.br

4 ModMolQSAR, Faculdade de Farmácia, Universidade Federal do Rio de Janeiro (UFRJ), Rio de Janeiro CEP 21941-902, RJ, Brazil; E-Mail: rangelfarmacia@gmail.com

5 LABiEMOL, Departamento de Biologia Celular e Molecular, Universidade Federal Fluminense (UFF), Niterói CEP 24033-900, RJ, Brazil

* Authors to whom correspondence should be addressed;

E-Mails: hcastrorangel@yahoo.com.br (H.C.C.); lmcabral2@yahoo.com.br (L.M.C.); Tel.: +55-21-2629-9954 (H.C.C); +55-21-3938-6605 (L.M.C.)

Academic Editor: Derek J. McPhee

Received: 27 February 2015 / Accepted: 13 April 2015 / Published: 20 April 2015

Abstract: The incidence of hematological disorders has increased steadily in Western countries despite the advances in drug development. The high expression of the multi-resistance protein 4 in patients with transitory aspirin resistance, points to the importance of finding 
new molecules, including those that are not affected by these proteins. In this work, we describe the synthesis and biological evaluation of a series of $N, N^{\prime}$-disubstituted thioureas derivatives using in vitro and in silico approaches. New designed compounds inhibit the arachidonic acid pathway in human platelets. The most active thioureas (compounds 3d, 3i, 3m and 3p) displayed $\mathrm{IC}_{50}$ values ranging from 29 to $84 \mu \mathrm{M}$ with direct influence over in vitro $\mathrm{PGE}_{2}$ and $\mathrm{TXA}_{2}$ formation. In silico evaluation of these compounds suggests that direct blockage of the tyrosyl-radical at the COX-1 active site is achieved by strong hydrophobic contacts as well as electrostatic interactions. A low toxicity profile of this series was observed through hemolytic, genotoxic and mutagenic assays. The most active thioureas were able to reduce both $\mathrm{PGE}_{2}$ and $\mathrm{TXB}_{2}$ production in human platelets, suggesting a direct inhibition of COX-1. These results reinforce their promising profile as lead antiplatelet agents for further in vivo experimental investigations.

Keywords: thioureas; antiplatelet properties; in silico evaluation

\section{Introduction}

According to the World Health Organization, cardiovascular disease will be a leading cause of death in developed and developing countries by 2015. Currently, cardiovascular and thromboembolic events are already the major causes of death in Western countries [1].

Hemostasis is a widely studied topic due to the pathogenic nature of thrombotic and bleeding disorders $[2,3]$. The inappropriate activation of the hemostatic system contributes to the development of severe pathophysiological disorders, including the thromboembolic diseases, such as atherothrombosis and venous thromboembolism $[4,5]$.

In general, antithrombotic drugs, including antiplatelet agents (e.g., clopidogrel, aspirin, tirofiban), are the primary treatment option for these diseases. However, they can lead to serious adverse reactions in some patients, including bleeding, neutropenia, thrombocytopenia and drug resistance [1,6-10]. Recent reports point to the highly expression of multidrug resistance protein 4 (MRP4) in platelets of patients with high incidence of transitory aspirin resistance [11]. MRP4 is an ATP-binding transporter which acts as an unidirectional pump for organic anionic compounds such as acetylsalicylate (the organic anion of aspirin) and is related to the extrusion of aspirin from platelets, reducing its pharmacological inhibition of cyclooxygenase-1 (COX-1) [12]. Suboptimal platelet inhibition by aspirin leads to an incomplete suppression of thromboxane generation, that is independently associated with increased risk of cardiovascular events [13].

Many non-steroidal anti-inflammatory drugs (NSAIDs) with antiplatelet activity due to COX-1 inhibition comprise the class of carboxylic acids, based on their ability to form strong salt-bridges with the guanidinium group of Arg120, located at the entrance of the cyclooxygenase site of COX-1 [14]. The role of this anchoring mechanism exemplifies that the ability of an acidic functional group to become anionic at physiological $\mathrm{pH}$ is a valuable structural and physicochemical feature of NSAIDs [15]. Unfortunately, the stable carboxylate anions formed by such compounds have a known 
tendency to interact with human organic anion transporters, such as multidrug resistance proteins (MRPs), that are often related to the undesired effects observed for many NSAIDs [16].

A variety of NSAIDs are able to interact with MRPs, with a higher specificity toward MRP4 [17], which suggests that other known NSAIDs bearing a carboxylic acid function are likely to be affected by biological resistance as observed for aspirin [11-13]. Therefore, based on the current literature, non-anionic COX-1 inhibitors may represent a potential alternative to current antiplatelet agents, prompting the development of a new drug class that has not been extensively investigated [18].

The thiourea moiety has been described as an important pharmacophore in a variety of promising chemical prototypes for drug development, including: anti-HIV (inhibitors of HIV capsid assembly) [19], anticancer [20], anticonvulsant [21], antimycobacterial [22], anti-HCV [23] and antimicrobial agents [24]. Recently the thiourea moiety was described for dual inhibition of both cyclooxygenase isoforms 1 and 2 with a 4-fold selectivity towards COX-2 active site [25], pointing its anti-inflammatory properties. The antithrombotic activity of this class of molecules was also explored as antagonists of the thrombin receptor PAR1 [26]. As the continued effort and identification of more effective compounds for the treatment of thrombotic diseases are still of considerable interest, in this work we developed a new series of non-anionic arylthiourea derivatives designed as novel antithrombotic agents targeting COX-1. Therefore, we synthesized a series of $N, N^{\prime}$-disubstituted thioureas $\mathbf{3 a}-\mathbf{q}$ and analyzed their in vitro and in silico antithrombotic profiles. In addition we explored their potential molecular targets as well as their toxicological profile.

\section{Results and Discussion}

\subsection{Chemistry}

In order to develop thioureas having an unlikely propensity to act as substrates for MRPs, the carboxylate function was rejected for the final products and replaced by hydrophobic or H-bond acceptor (HBA) groups unable to produce organic anions at physiological $\mathrm{pH}$. Therefore, we used aryl and alkyl groups substituents due to their hydrophobicity, pointed as a relevant feature to COX-1 selective inhibition when carboxylate groups are converted to less reactive acidic groups [18]. Co-substitutions of a potential lead molecule tailoring a HBA and a hydrophobic group was recently reported as an expressive approach for selective inhibition of cyclooxygenases, since it increases the molecular similarities to arachidonic acid by mimicking its 20 -carbon hydrophobic $\omega$-chain and the carboxylate group, which acts as a strong HBA group [25,27].

As a result of this rational design, a series of $N, N^{\prime}$-disubstituted thioureas was obtained using the general procedure as shown in Scheme 1. The desired thioureas $\mathbf{3 a}-\mathbf{q}$ were readily prepared through the reaction of the appropriate isothiocyanate $(\mathbf{1 a}-\mathbf{d})$ and an excess of amine $\mathbf{2}$, in a THF or tert-butanol solution (Table 1). The products were obtained in good to excellent yields $(82 \%-97 \%)$ and did not require any further purification after isolation from the crude reaction mixture by acidic extraction. The reactions used to obtain thioureas $\mathbf{3 e}-\mathbf{g}, \mathbf{3 j}, \mathbf{3 0}-\mathbf{q}$, between an aromatic amine and isothiocyanate required a reflux period due to the lower reactivity of the system, however these conditions did not compromise the yields (Table 1). The proposed structures of all prepared compounds were confirmed by FTIR, ${ }^{1} \mathrm{H}-\mathrm{NMR},{ }^{13} \mathrm{C}-\mathrm{NMR}$ and HRMS. 
<smiles>[R]c1cc(C=NC=NC=C=S)cc([R])c1[R]</smiles>

1a $(n=0 ; R=H)$

1b $(n=1 ; R=H)$

$1 c(n=2 ; R=H)$

1d $\left(\mathrm{n}=0 ; \mathrm{R}=\mathrm{OCH}_{3}\right)$<smiles>CNC(=S)Nc1ccccc1</smiles>

3a<smiles>S=C(Nc1ccccc1)NC1CCCCC1</smiles>

$3 b$

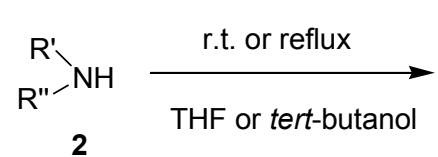<smiles>[R]c1cc(CNC(=S)N([R])[R])cc([R])c1[R]</smiles><smiles>COc1cc(NC(=S)Nc2ccccc2)cc(OC)c1OC</smiles><smiles>OCCNC(=S)Nc1ccccc1</smiles>

3c<smiles>CCN(CC)C(=S)Nc1ccccc1</smiles>

$3 d$<smiles>S=C(Nc1ccccc1)Nc1ccc2c(c1)OCO2</smiles><smiles>S=C(Nc1ccccc1)Nc1cccc2ccccc12</smiles><smiles>CC(C)NC(=S)NCc1ccccc1</smiles>

3h<smiles>CCN(CC)C(=S)NCc1ccccc1</smiles>

$3 \mathbf{i}$<smiles>S=C(NCc1ccccc1)Nc1ccc2c(c1)OCO2</smiles>

3j<smiles>CC(C)NC(=S)NCCc1ccccc1</smiles>

3k<smiles>CCCCNC(=S)NCCc1ccccc1</smiles>

31<smiles>CCN(CC)C(=S)NCCc1ccccc1</smiles>

$3 m$<smiles>S=C(NCCc1ccccc1)NC1CCCCC1</smiles>

$3 n$<smiles>S=C(NCCc1ccccc1)Nc1cccc2ccccc12</smiles><smiles>S=C(NCCc1ccccc1)Nc1ccc2c(c1)OCO2</smiles><smiles>COc1cc(NC(=S)Nc2ccc3c(c2)OCO3)cc(OC)c1OC</smiles>

Scheme 1. Synthesis of thiourea derivatives from isothiocyanates. 
Table 1. Reaction conditions and yields for thioureas 3a-q produced using Scheme 1.

\begin{tabular}{|c|c|c|c|c|}
\hline Thiourea & Solvent & Temperature & Time (h) & Yield $\%{ }^{a}$ \\
\hline $\mathbf{3 a}$ & THF & r.t. & 4.0 & 97 \\
\hline $\mathbf{3 b}$ & THF & r.t. & 8.0 & 90 \\
\hline $3 c$ & THF & r.t. & 6.0 & 89 \\
\hline 3d & THF & r.t. & 6.0 & 96 \\
\hline $3 \mathbf{e}$ & $t-\mathrm{BuOH}$ & reflux & 8.0 & 82 \\
\hline $3 f$ & $t-\mathrm{BuOH}$ & reflux & 10.0 & 92 \\
\hline $3 g$ & $t-\mathrm{BuOH}$ & reflux & 7.0 & 86 \\
\hline $3 \mathbf{h}$ & THF & r.t. & 5.0 & 85 \\
\hline $3 \mathbf{i}$ & THF & r.t. & 6.0 & 95 \\
\hline $3 \mathbf{j}$ & $t-\mathrm{BuOH}$ & reflux & 10.0 & 85 \\
\hline $3 \mathbf{k}$ & THF & r.t. & 5.0 & 89 \\
\hline 31 & THF & r.t. & 4.5 & 89 \\
\hline $3 m$ & THF & r.t. & 4.0 & 88 \\
\hline $3 n$ & THF & r.t. & 6.0 & 88 \\
\hline 30 & $t-\mathrm{BuOH}$ & reflux & 8.0 & 87 \\
\hline $3 p$ & $t-\mathrm{BuOH}$ & reflux & 12.0 & 94 \\
\hline $3 q$ & $t-\mathrm{BuOH}$ & reflux & 8.0 & 84 \\
\hline
\end{tabular}

a Isolated yield.

\subsection{Biological Activity Evaluation}

\subsubsection{Platelet Aggregation Assays}

In physiological conditions, the release of arachidonic acid (AA) from the platelet membranes generates thromboxane $\mathrm{A}_{2}\left(\mathrm{TXA}_{2}\right)$, a potent platelet agonist, leading to shape-change, granule release and platelet aggregation [28,29]. The main enzymes responsible for the production of TXA 2 in platelets are COX-1 and thromboxane synthase (TXS), both whose inhibition is known to prevent platelet aggregation [30,31].

Aggregation of healthy human platelets induced by arachidonic acid revealed the antiplatelet activity of compounds $\mathbf{3 d}, \mathbf{3 m}, \mathbf{3} \mathbf{i}$ and $\mathbf{3 p}$, that were able to inhibit AA-induced platelet aggregation in a range of $96 \%-98 \%$, statistically similar to aspirin $(97.5 \%)$ at the same concentration $(100 \mu \mathrm{M})$ (Figure 1). These results pointed to the efficacy of our proposal on the production of novel antiplatelet thioureas.

The concentrations that caused 50\% inhibition of platelet aggregation revealed compound $\mathbf{3 d}$ $\left(\mathrm{IC}_{50}=29.1 \mu \mathrm{M} \pm 2.0\right)$ as the most potent of the series followed by $\mathbf{3 m}\left(\mathrm{IC}_{50}=34.5 \mu \mathrm{M} \pm 0.9\right), \mathbf{3 p}$ $\left(\mathrm{IC}_{50}=84.6 \mu \mathrm{M} \pm 0.5\right)$ and $3 \mathbf{i}\left(\mathrm{IC}_{50}=86.2 \mu \mathrm{M} \pm 0.3\right)$ (Figure 1). These data revealed the potency of these antiplatelet thiourea derivatives to inhibit the arachidonic acid pathway of platelet aggregation and suggests their ability to reduce the TXA 2 production as a mechanism to impair normal platelet aggregation. 


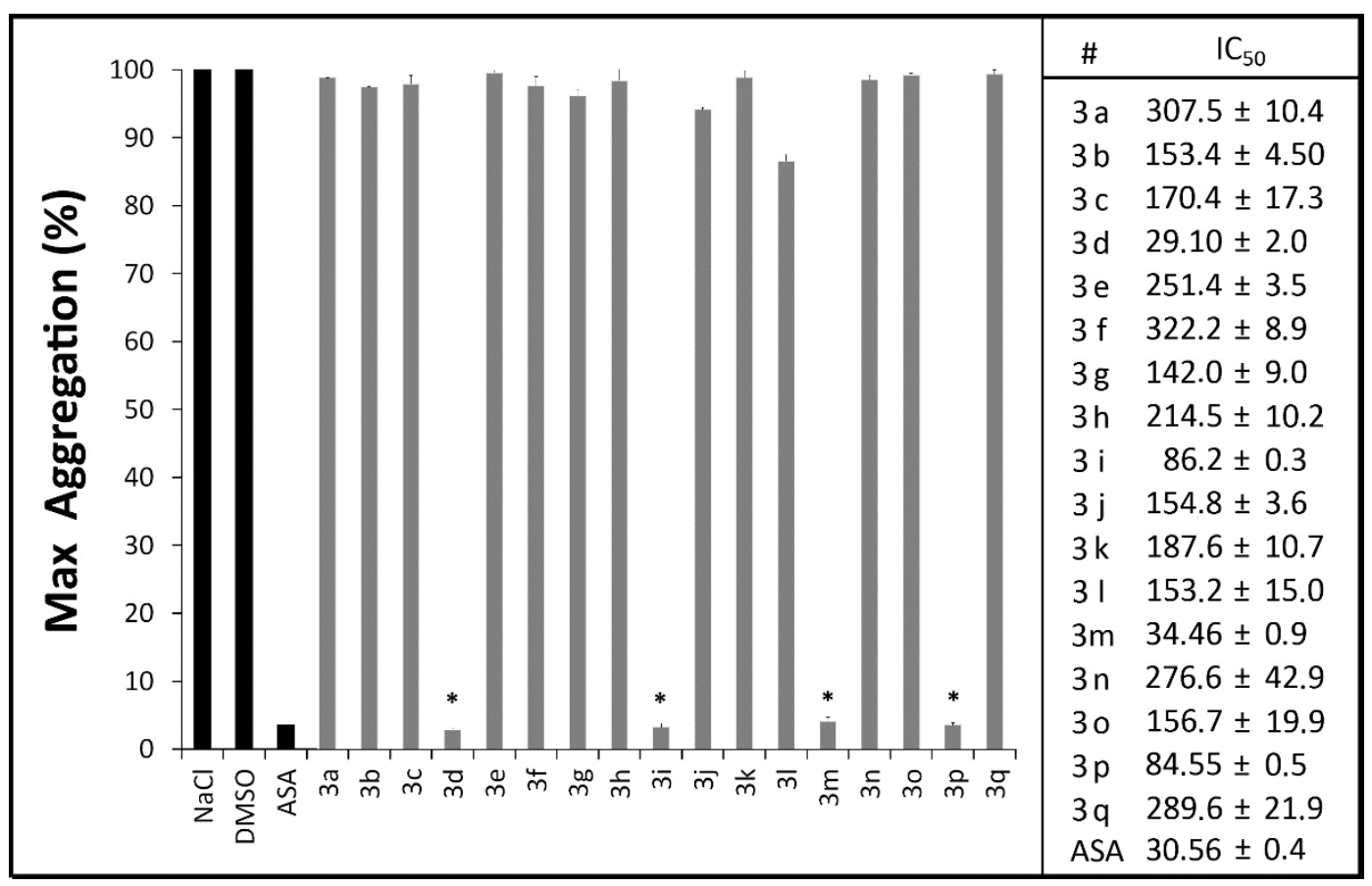

Figure 1. Antiplatelet profile of $N, N^{\prime}$-disubstituted thiourea derivatives $(100 \mu \mathrm{M})$ and aspirin (ASA) on in vitro platelet aggregation of human citrated platelet-rich plasma induced by arachidonic acid (AA). The results are the mean of two experiments performed in triplicate. $* p<0.05$ (oneway ANOVA, Tukey test).

\subsubsection{Measurement of Plasma $\mathrm{PGE}_{2}$ and $\mathrm{TXB}_{2}$ Levels}

The stable direct metabolite of $\mathrm{PGE}_{2}, 13$,14-dihydro-15-keto-Prostaglandin $\mathrm{E}_{2}$, is a known marker of the COX-1 activity [32,33]. By the measurement of total levels of this $\mathrm{PGE}_{2}$ metabolite in human platelet-rich plasma, we evaluated the feasibility of antiplatelet $N, N^{\prime}$-disubstituted thioureas to inhibit COX-1 activity in healthy platelets (Table 2).

Table 2. Effects of novel antiplatelet $N, N^{\prime}$-disubstituted thiourea derivatives $(100 \mu \mathrm{M})$ on $\mathrm{PGE}_{2}$ and $\mathrm{TXB}_{2}$ production determined by Enzyme Immunoassay (EIA) in comparison to dimethylsulfoxide (DMSO, 1\%), Ozagrel $(100 \mu \mathrm{M})$, Aspirin $(100 \mu \mathrm{M})$ and Indomethacin $(100 \mu \mathrm{M})$.

\begin{tabular}{ccc}
\hline$\#$ & $\begin{array}{c}\text { Platelet Inhibition of } \\
\mathbf{P G E}_{\mathbf{2}} \mathbf{( \% )}\end{array}$ & $\begin{array}{c}\text { Platelet Inhibition of } \\
\mathbf{T X B}_{\mathbf{2}} \mathbf{( \% )}\end{array}$ \\
\hline $\mathbf{3 d}$ & $25.6 \pm 5.9$ & $74.2 \pm 10.2$ \\
$\mathbf{3 i}$ & $21.1 \pm 5.0$ & $74.7 \pm 5.5$ \\
$\mathbf{3 m}$ & $28.2 \pm 5.9$ & $91.2 \pm 0.0$ \\
$\mathbf{3 p}$ & $7.9 \pm 7.9$ & $88.1 \pm 5.5$ \\
Aspirin & $47.5 \pm 1.4$ & $78.5 \pm 5.0$ \\
Indomethacin & $28.0 \pm 1.6$ & $99.8 \pm 0.0$ \\
Ozagrel & - & $98.0 \pm 2.8$ \\
DMSO & $0.0 \pm 1.6$ & $0.0 \pm 0.0$ \\
\hline
\end{tabular}


Similar inhibition rates observed for indomethacin for $\mathrm{PGE}_{2}$ production were obtained by these antiplatelet thioureas at the same concentration $(100 \mu \mathrm{M})$ suggesting a mechanism of action equally efficient to a known clinical drug. Aspirin $(100 \mu \mathrm{M})$ showed higher inhibition of PGE2 production (47.5\%) in comparison to indomethacin and the thiourea derivatives, which might be related to the non-competitive inhibition of COX-1 by aspirin through selective acetylation of Ser530 [34]. Previous studies have demonstrated the anti-inflammatory role of thiourea derivatives in xylene-induced ear swelling in mice, with mild COX-1 inhibition in comparison to aspirin [35], which suggested a mechanism of action that diverges from that of acetylsalicylic acid.

Thromboxane $\mathrm{B}_{2}\left(\mathrm{TXB}_{2}\right)$, a stable TXA 2 metabolite, is widely used as a prognostic risk marker of platelet activation in cardiovascular disease, which is closely related to COX-1 and Thromboxane Synthetase activity $[29,36]$. Thus, the plasma levels of this metabolite were measured using an enzyme immunoassay (EIA) as described in the Experimental Section.

Table 3. Mutagenic and genotoxic activity of thiourea derivatives without metabolic activation evaluated by Ames test and SOS chromotest. The thiourea derivatives were dissolved in dimethylsulfoxide (DMSO) to perform assays. As positive control 4-NQO was used. Results of three different concentrations $(10 \mu \mathrm{M}, 100 \mu \mathrm{M}$ and $500 \mu \mathrm{M})$.

\begin{tabular}{|c|c|c|c|c|c|c|}
\hline \multirow{2}{*}{ Thiourea } & \multicolumn{4}{|c|}{ Ames Test $S$. typhimurium } & \multicolumn{2}{|c|}{ SOS Chromotest E. coli } \\
\hline & TA97 & TA98 & TA100 & TA102 & PQ35 & PQ37 \\
\hline $3 a$ & - & - & - & - & - & - \\
\hline $3 \mathbf{b}$ & - & - & - & - & - & - \\
\hline $3 c$ & - & - & - & - & - & - \\
\hline 3d & - & - & - & - & - & - \\
\hline $3 e$ & - & - & - & - & - & - \\
\hline 3f & - & - & - & - & - & - \\
\hline $3 g$ & - & - & - & - & - & - \\
\hline $3 \mathbf{h}$ & - & - & - & - & - & - \\
\hline $3 \mathbf{i}$ & - & - & - & - & - & - \\
\hline $3 \mathbf{j}$ & - & - & - & - & - & - \\
\hline $3 k$ & - & - & - & - & - & - \\
\hline 31 & - & - & - & - & - & - \\
\hline $3 m$ & - & - & - & - & - & - \\
\hline $3 n$ & - & - & - & - & - & - \\
\hline 30 & - & - & - & - & - & - \\
\hline $3 p$ & - & - & - & - & - & - \\
\hline $3 q$ & - & - & - & - & - & - \\
\hline 4-NQO & + & + & + & + & + & + \\
\hline DMSO & - & - & - & - & - & - \\
\hline ASA & - & - & - & - & - & - \\
\hline
\end{tabular}

The reduced production of $\mathrm{TXB}_{2}$ in platelet-rich plasma induced by the presence of the thiourea derivatives $\mathbf{3 d}, \mathbf{3 i}, \mathbf{3 m}$ and $\mathbf{3 p}$ presented similar inhibition rates in comparison to aspirin (78.5\%), including the most active molecules $\mathbf{3} \mathbf{m}$ (91\%) and $\mathbf{3 p}$ (88\%) (Table 3). These data prompt the potential of this series of compounds as new non anionic antiplatelet agents against human plasma. Interestingly, 
we observed a direct correlation between the production of $\mathrm{TXB}_{2}$ and the length of the alkyl chain of the thiourea derivatives, whereby the phenethyl-substituted thiourea $\mathbf{3 m}$ displayed a better inhibitory activity in comparison to its benzyl (3i) or phenyl (3d) analogs.

The ability of thioureas to reduce the platelet production of $\mathrm{TXB}_{2}$ and aggregation has been previously discussed [37], alongside with its vasoactive effects, such as reducing vascular hypertension at a similar magnitude to commercial non-steroidal anti-inflammatory drugs [38]. Studies suggest that the reduced $\mathrm{TXB}_{2}$ production by platelets after treatment with thiourea occurs due to the scavenging properties of hydroxyl radicals [39], a common property for thiourea compounds, which display antioxidant properties [40]. However, Scholz and collaborators suggested that COX-1 inhibition has no correlation to the inactivation of hydroxyl radicals but rather to structural properties of the ligands, able to improve binding affinity [41].

Currently, the literature reports that the basic structural requirements for selective inhibition of TXS are a 1-imidazolyl or a 3-pyridyl moiety at one end of the molecule (to block the heme iron through strong pi-cation interactions) $[18,42]$ and a carboxylic acid at the other end to orient the molecule in a similar binding mode to prostaglandin $\mathrm{H}_{2}[43,44]$. Importantly, both structural requirements are not fulfilled by any of the thiourea derivatives described herein, supporting the potential of this series as feasible COX-1 inhibitors.

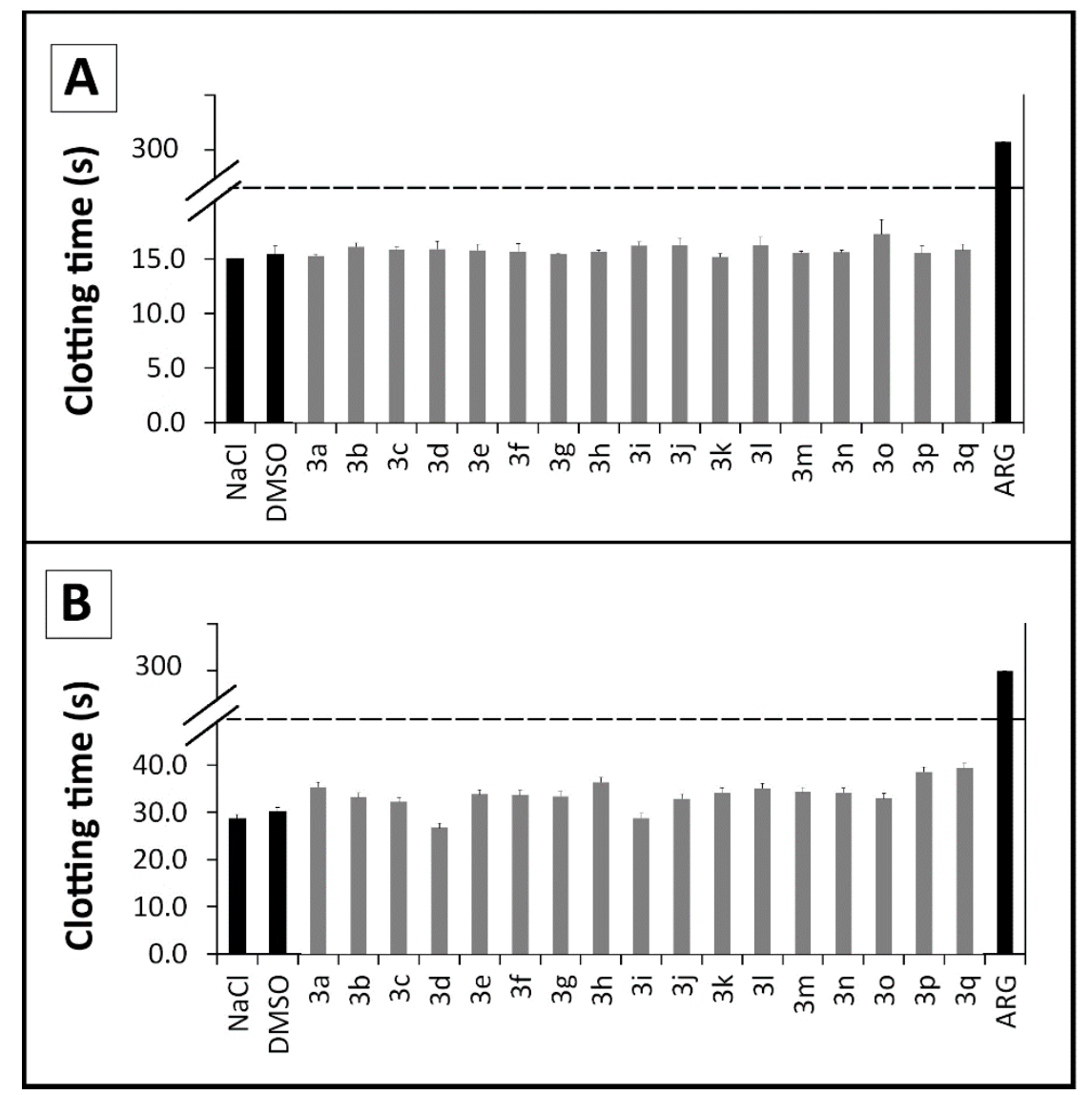

Figure 2. Evaluation of $N, N^{\prime}$-disubstituted thiourea derivatives and argatroban (ARG) on the in vitro coagulation of human pooled plasma $(n=6)$ by activated partial thromboplastin time - aPTT (A) and prothrombin time-PT (B) assays. All derivatives and argatroban at $100 \mu \mathrm{M}$; DMSO at $1 \%$ and $\mathrm{NaCl}$ at $0.25 \mathrm{M}$. 


\subsubsection{Coagulation Assays}

To verify whether the plasmatic phase of blood coagulation was affected by these new compounds, we investigated the influence of these novel thiourea compounds $\mathbf{3 a}-\mathbf{q}$ in human pooled plasma $(n=6)$ on routine coagulation assays (activated partial thromboplastin time — aPTT, and prothrombin time-PT) [45]. Neither the extrinsic nor intrinsic pathways of the coagulation cascade were influenced by the presence of the compounds, suggesting that the antithrombotic profile of the compounds described herein relies on the direct impairment of platelet aggregation, thus differing from dual action molecules (Figure 2). This result reveals a small bleeding risk in comparison to dual acting molecules whose mechanism often lead to severe bleeding disorders as described in the literature [46,47].

\subsubsection{In Vitro Toxicity Assays}

The literature shows that the interaction between chemical derivatives and erythrocytes may accelerate cell aging or lead to a mechanical premature destruction of these cellular integrity with release of hemoglobin. According to our erythrocyte lysis assay no significant hemolytic profile was observed for thioureas 3a-q (Figure 3) after a $3 \mathrm{~h}$ incubation period ( $0 \%-9 \%)$. They were similar to aspirin (2\%) $(p \leq 0.05)$ and not comparable to Triton X-100 (100\%), used as a positive control. Fisher and collaborators [48] reported that hemolysis values below $10 \%$ are considered non-hemolytic, which frame these compounds within an acceptable toxicity profile [48-50].

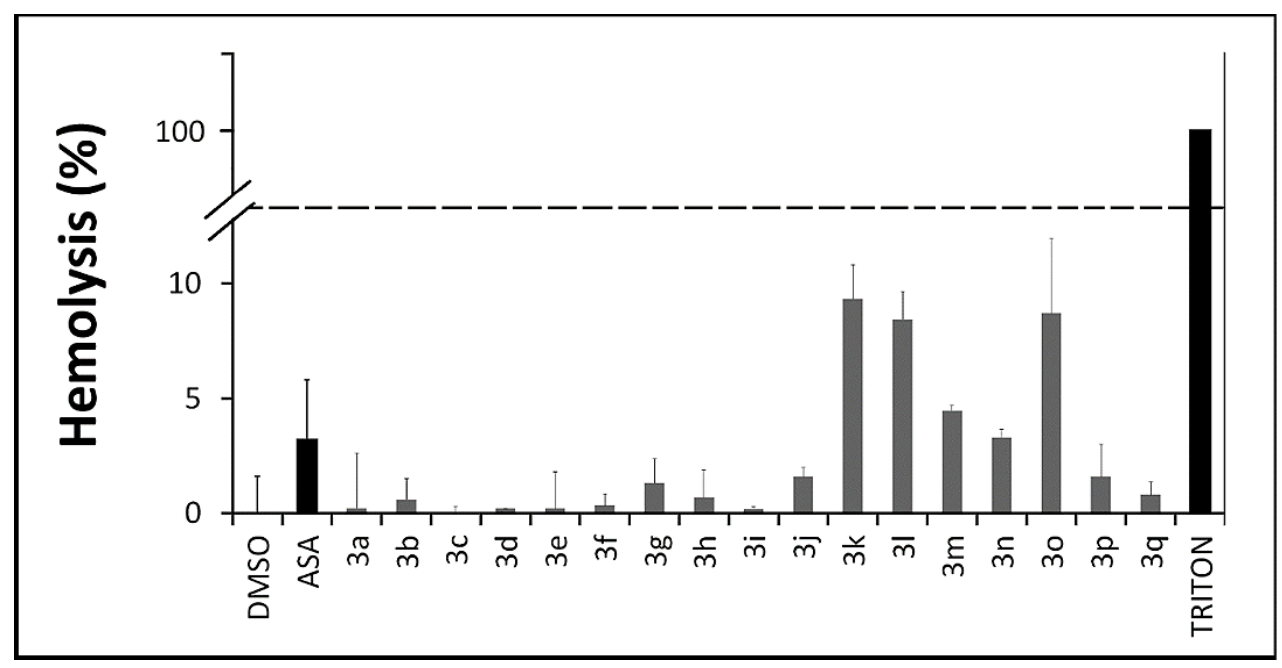

Figure 3. Evaluation of the hemolytic profile of $N, N^{\prime}$-disubstituted thioureas through hemolysis assays over a $3 \mathrm{~h}$ period. Values below 10\% are considered non hemolytic. All derivatives and ASA at $100 \mu \mathrm{M}$; DMSO and TRITON at $1 \%$.

This safe profile is reinforced by further toxicological studies which revealed no mutagenicity profiles against Salmonella typhimurium auxotroph mutant strains for all thiourea derivatives through reverse mutagenesis and histidine prototrophy (Ames test), compared to the positive control 4-nitro-quinoline 1-oxide (4NQO) [51,52], nor genotoxicity profiles, that was evaluated against Escherichia coli through the SOS chromotest [53]. This low risk profile is maintained even at the highest concentrations tested $(500 \mu \mathrm{M}$, Table 3$)$, revealing the safety profile of the series as promising for lead prototypes. 


\subsection{Computational Analysis}

\subsubsection{Structure-Activity Relationship Studies (SAR)}

In this work we evaluated different electronic parameters for all compounds (Table 4). Overall, the thiourea derivatives share a similar electronic profile for HOMO $(-7.73$ to $-8.34 \mathrm{eV})$ and LUMO energies (2.18 to $3.72 \mathrm{eV}$ ). Interestingly, combining different hydrophobic groups with the HBA $\mathrm{N}, \mathrm{N}$-diethyl group, resulted in the most active molecules (compounds $\mathbf{3 d}, \mathbf{3 i}, \mathbf{3 m}$ and $\mathbf{3 p}$ ) supporting our initial design strategy as an interesting method to develop antiplatelet agents bearing similarities to arachidonate [54].Co-substitutions of thioureas with the hydrophobic aliphatic chains at the side derived from isothiocyanate (Scheme 1) increase the molecular similarities to AA, by mimicking its 20-carbon hydrophobic $\omega$-chain [27].

Table 4. The stereoelectronic properties of $N, N^{\prime}$-disubstituted thioureas. $\mathrm{DM}=$ dipole moment (debye); PSA = polar surface area $\left(\AA^{2}\right), \operatorname{clog} \mathrm{P}=$ octanol/water partition coefficient, $\mathrm{MW}=$ molecular weight, $\mathrm{HBD}=$ hydrogen bond donors, HBA = hydrogen bond acceptors.

\begin{tabular}{|c|c|c|c|c|c|c|c|c|c|c|}
\hline \multirow{2}{*}{ \# } & \multirow{2}{*}{$\begin{array}{c}E^{\text {HOMO }} \\
(\mathrm{eV}) \\
\end{array}$} & \multirow{2}{*}{$\begin{array}{c}E^{\text {LUMO }} \\
(\mathrm{eV})\end{array}$} & \multirow{2}{*}{ DM } & \multirow{2}{*}{$\begin{array}{c}\text { AREA } \\
\left(\AA^{2}\right)\end{array}$} & \multirow{2}{*}{$\begin{array}{c}\text { VOLUME } \\
\left(\AA^{3}\right)\end{array}$} & \multirow{2}{*}{ PSA } & \multicolumn{4}{|c|}{ Lipinski Rule of Five } \\
\hline & & & & & & & MW & $\operatorname{clog} \mathbf{P}$ & HBD & HBA \\
\hline 3a & -8.34 & 3.12 & 5.82 & 196.34 & 172.56 & 20.237 & 166.25 & 1.99 & 2 & 3 \\
\hline $3 \mathbf{b}$ & -8.27 & 3.15 & 5.78 & 272.63 & 251.41 & 18.336 & 234.37 & 3.52 & 2 & 3 \\
\hline $3 c$ & -8.24 & 3.22 & 5.66 & 225.92 & 198.74 & 39.126 & 196.27 & 1.48 & 3 & 4 \\
\hline 3d & -8.19 & 3.01 & 5.21 & 248.09 & 227.35 & 11.734 & 208.33 & 3.05 & 1 & 3 \\
\hline $3 e$ & -7.95 & 2.7 & 6.94 & 331.01 & 315.91 & 40.151 & 318.4 & 3.28 & 2 & 6 \\
\hline 3f & -7.73 & 2.85 & 6.16 & 272.97 & 259.97 & 37.832 & 272.33 & 3.44 & 2 & 5 \\
\hline $3 g$ & -7.64 & 2.13 & 6.43 & 293.95 & 285.88 & 20.889 & 278.38 & 4.66 & 2 & 3 \\
\hline $3 \mathrm{~h}$ & -8.26 & 3.52 & 6.17 & 257.56 & 228.28 & 19.745 & 208.33 & 2.72 & 2 & 3 \\
\hline $3 \mathbf{i}$ & -8.19 & 3.58 & 5.60 & 276.39 & 247.98 & 9.5490 & 222.36 & 3.12 & 1 & 3 \\
\hline $3 \mathbf{j}$ & -8.10 & 3.16 & 5.94 & 303.20 & 281.49 & 35.421 & 286.36 & 3.51 & 2 & 5 \\
\hline $3 k$ & -8.26 & 3.65 & 5.78 & 276.49 & 246.67 & 19.462 & 222.36 & 3.00 & 2 & 3 \\
\hline 31 & -8.27 & 3.64 & 5.62 & 295.98 & 265.13 & 20.208 & 236.38 & 3.58 & 2 & 3 \\
\hline $3 m$ & -8.21 & 3.72 & 5.15 & 294.52 & 266.42 & 9.4050 & 236.38 & 3.40 & 1 & 3 \\
\hline $3 n$ & -8.21 & 3.68 & 5.79 & 312.13 & 288.54 & 18.806 & 262.42 & 3.89 & 2 & 3 \\
\hline 30 & -7.92 & 2.18 & 5.66 & 343.86 & 325.92 & 18.886 & 306.43 & 5.00 & 2 & 3 \\
\hline $3 p$ & -8.05 & 3.15 & 5.82 & 320.69 & 299.61 & 34.234 & 300.38 & 3.79 & 2 & 5 \\
\hline $3 q$ & -7.85 & 2.69 & 6.86 & 356.02 & 341.05 & 56.282 & 362.41 & 3.06 & 2 & 8 \\
\hline
\end{tabular}

Substitutions on the thiourea moiety by replacing acceptor groups at R' and R" lead to less active compounds (3a, 3b, 3g, 3h, 3k, 3l, 3n and 3o), suggesting that the prevalence of a hydrogen-bond acceptor group in R" over of a donor group is favorable to the antiplatelet activity of this series. In addition, compounds with a hydrogen-bond acceptor group (R' and R") in the absence of aliphatic chain (3e, 3f) lack antiplatelet activity as well as compounds bearing HBA groups at the both sides of thiourea moiety (3q), which reinforce the importance of having a design resulted from the combination of a HBA group with a hydrophobic group. Increasing the length of the aliphatic chain of methylenedioxy-substituted thiourea, from phenyl (3f) and benzyl (3j) to phenethyl (3p) led to an 
improvement of antiplatelet activity ( $\mathrm{IC}_{50}=84.5 \mu \mathrm{M}$-Figure 1). The increase of chain length of bioactive molecules for improved lipophilicity have been reported as a relevant parameter to inhibit human platelet aggregation [55], as it increases the affinity of the molecule towards COX-1 and facilitates passive transport across biological membranes [15]. Interestingly, substitution of the methyl group in thiourea 3a by an $N, N$-diethyl group (3d) replaced the H-bond donor profile by an acceptor one, leading to a successful combination that resulted in the most active compound (Table 4). Increasing chain length from phenyl (3d) to benzyl-substituted thiourea (3i) reduced potency by nearly three-fold, while no expressive reduction was observed for the phenethyl-substituted thiourea (3m) (Figure 1).

The evaluation of this novel series of thiourea derivatives reinforced lipophilicity as an important feature for modulating the antiplatelet activity, since the substitution by longer hydrophobic groups at the region derived from the isothiocyanate, preferably opposed by a polar electron-rich hydrogen-bond acceptor group (e.g., methylenedioxy or $N, N$-diethyl groups at $\mathrm{R}^{\prime}$ and $\mathrm{R} "$ ), increased the biological activity of all compounds, except for thiourea 3d, which may have a different mechanism of action apart from the establishment of low $\Delta \mathrm{G}$ complexes with the enzyme. Our data suggests the importance of the substitution of the thiourea moiety with a $N, N$-diethyl group, leading to a high antiplatelet activity profile.

Literature describes that COX-1 is located into dense tubule structures inside platelets [56]. Primary eicosanoids, such as arachidonate and thromboxane $\mathrm{A}_{2}$, are not able to diffuse passively through platelets membranes and require active transport by human organic anion transporters such as MRP4 [57]. This suggests the importance of cell permeability for non-anionic compounds such as the thioureas presented herein. Recent studies also point to the relevance of hydrophobicity management for COX-1 selective inhibition when carboxylate groups of known ligands are converted to less reactive groups [18] and our data supports the accuracy of that point.

\subsubsection{Docking Analysis}

All $N, N^{\prime}$-disubstituted thiourea derivatives were docked into the active site of the ovine COX-1 (PDB ID: 2OYE) and Thromboxane Synthase (TXS) [44]. The theoretical complexes were evaluated and ranked by number of clusters, number of conformations at the lowest energy cluster, binding energy, and number of interactions (Figure 4). Notably, all compounds presented a lower number of different clusters in COX-1 when compared to the TXS derivatives complexes which lead to an increased numbers of stable poses observed for COX-1. This data corroborate to previous studies that determine the structural determinants for TXS inhibition [43] which are not addressed by any of the thiourea derivatives described herein. This theoretical data reinforce the feasibility of these molecules as COX-1 inhibitors.

Docking results showed that phenethyl-substituted molecules $3 \mathbf{k}-\mathbf{p}$ formed complexes with higher stability to the enzyme in comparison to their phenyl or benzyl-substituted analogs (Figure 4). This results reinforced the correlation between lipophilicity and binding affinity to COX-1 [18]. Interestingly, the carbonyl backbone of Ile523 from COX-1 was able to establish hydrogen bonds (2.0 $⿱$ ) with NH group from the thiourea moiety in 13 of the 17 thiourea complexes, having $\mathbf{3 c}, \mathbf{3 d}, \mathbf{3 g}$ and $\mathbf{3 o}$ as exceptions (Figure 4). 


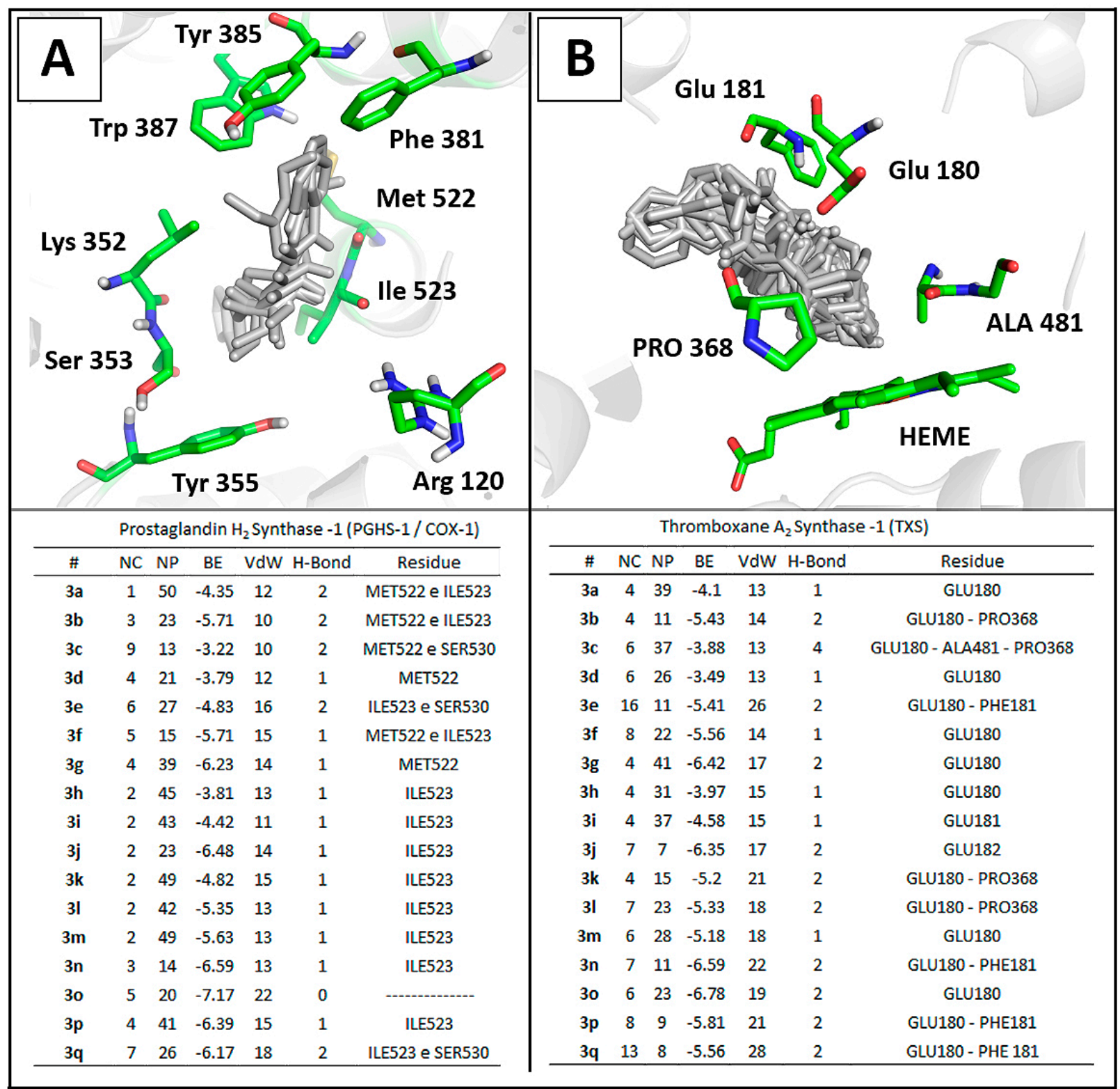

Figure 4. Comparison of molecular docking complexes of $N, N^{\prime}$-disubstituted thioureas with (A) the crystallographic structure of ovine COX-1 (PDB ID: 2OYE) and (B) a three-dimensional model of human thromboxane synthase [29]. Interaction panels include number of clusters (NC), number of poses in the lowest energy cluster (NP), binding energy score (BE) and intermolecular interactions: Van der Waals (VdW) and hydrogen bonds (H-bond).

This feature might be involved in the recognition and activity of thiourea derivatives against COX-1. Literature points that the I523V mutation in COX-1 decreases the cyclooxygenase activity by $30 \%$ suggesting the catalytic relevance of Ile523 in COX-1 to the conversion of AA into $\mathrm{PGG}_{2}$ [58]. In COX-1, Ile523 reduces the space of the hydrophobic cavity that is available in COX-2 due to the replacement of isoleucine by valine [59]. Furse et al. described the mechanism using a molecular dynamics approach and reported that the arachidonic acid (AA) is oxygenated by PGHS1, revealing that AA displays considerably less conformational flexibility in COX-1 in comparison to COX-2. This points the importance of Ile523 to maintain AA in a catalytically favorable orientation towards Tyr385 during the enzymatic process [60]. This process might be impaired by stable thiourea complexes formed. 
The enzyme-ligand complex analysis revealed that phenyl, benzyl and phenethyl groups were orientated towards the hydrophobic channel near Tyr385 for all compounds, with the other substituent at $\mathrm{R}^{\prime}$ and $\mathrm{R}^{\prime \prime}$, such as 3,4-methylenedioxyphenyl or $N, N$-diethyl, orientated towards the active site entrance to meet Arg120 and Tyr355 (Figure 4). This orientation is similar to those described for many NSAIDs. One of the most important interaction involves Arg 120 in a salt-bridge interaction with the ligand carboxylate anion and lipophilic groups buried into the hydrophobic channel of the enzyme [61-63].

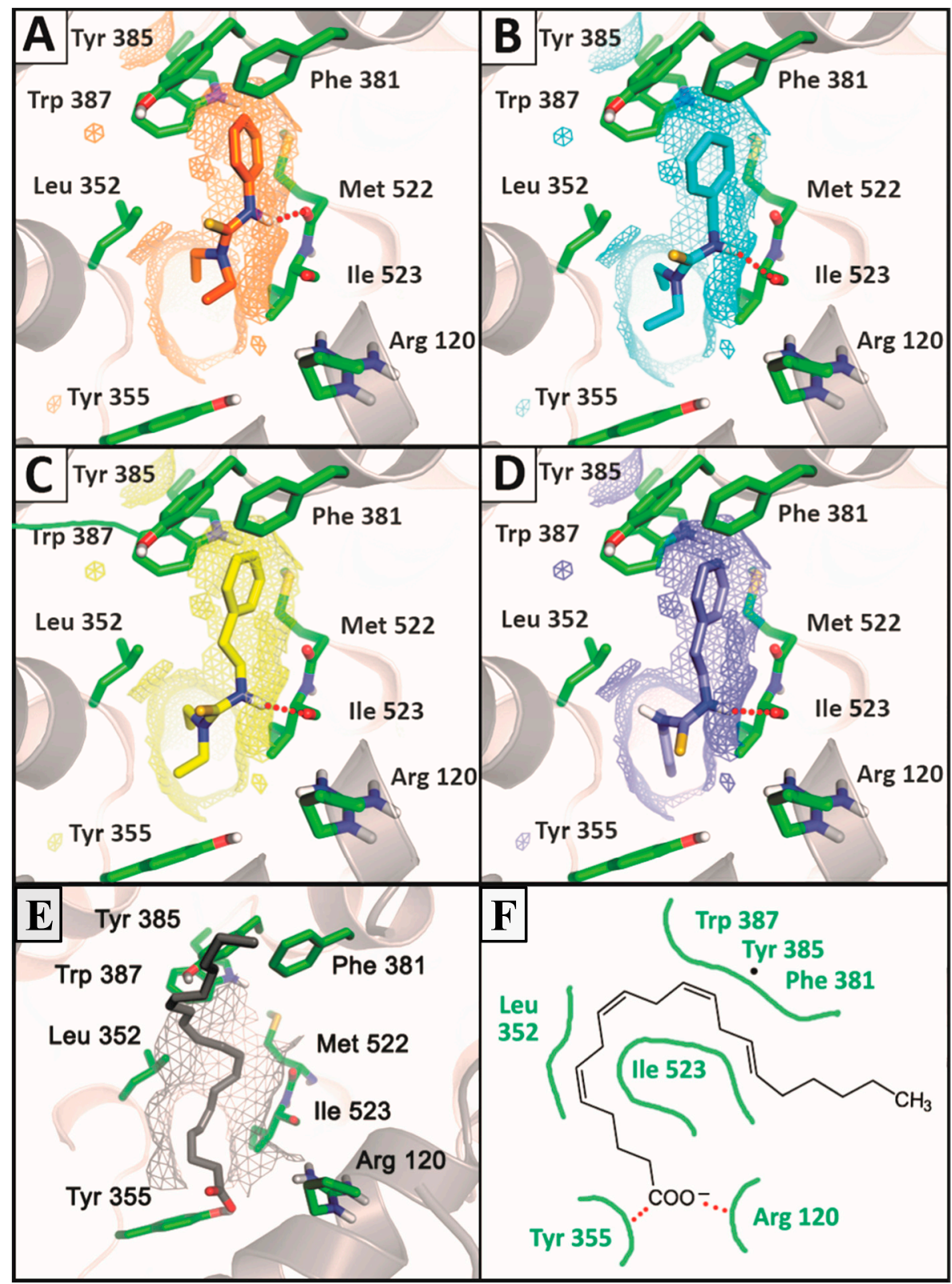

Figure 5. Comparison of the most stable poses observed for the active compounds $3 \mathbf{d}$ (A), 3i $(\mathbf{B}), 3 \mathbf{m}(\mathbf{C}), \mathbf{3 p}(\mathbf{D})$ and arachidonic acid $(\mathbf{E}, \mathbf{F})$ with the crystallographic structure of ovine COX-1 (PDB ID: 2OYE). Hydrogen bounds are shown as red balls.

Such a feature has direct relationship to the biological activity of these agents accordingly to crystal structures from ovine COX-1 complexed with AA. The carboxylate group of the substrate interacts with the guanidinium group of Arg120 and establishes a hydrogen bond to Tyr355, while the aliphatic 
backbone go toward the hydrophobic channel of the catalytic site, bending in the vicinity of Tyr385 [64]. Such binding mode is achieved preferably by phenethyl-substituted compounds in addition to a co-substitution by methylenedioxy (3p) or $N, N$-diethyl groups $(\mathbf{3 m})$ and generates high stable complexes with COX-1. This suggests a feasible blockage of active site from arachidonic acid recognition (Figure 5).

The phenyl-substituted thiourea 3d displayed the best antiplatelet profile of the series with the lowest influence on the production of $\mathrm{TXB}_{2}$ by activated platelets. Docking analysis revealed that this compound binds to the catalytic site of COX-1 with lower affinity in comparison to benzyl (3i) and phenethyl-substituted (3m) derivatives (Figure 5). However, due to the hydrophobicity of the phenyl group and the hydrogen bond acceptor profile of $N, N$-diethyl group, thiourea $3 \mathbf{d}$ is able to display a similar orientation to arachidonic acid and the phenethyl-substituted derivatives in the active site of the enzyme (Figure 5). In addition, the smaller size of the phenyl group allows the thiourea moiety to be inserted closer to Tyr385 in comparison to benzyl or phenethyl-substituted molecules, whereas it is able to establish a H-bond with Met522 rather than Ile523.

COX-1 inhibitors are known to bind near the top of the hydrophobic channel and affect interactions with Tyr385 [65]. According to literature, the COX-1-mediated catalysis of arachidonic acid requires the formation of a tyrosyl radical from Tyr385 through oxidation of the heme iron after reaction with endogenous peroxides [66]. The tyrosyl radicals are transient and rapidly dissipated by reductants, suggesting that COX-1-mediated catalysis might be vulnerable to suppression by antioxidant molecules [40,67]. Wu et al., reported that the carboxylic acid of diclofenac binds in a non-canonical way to the top of the hydrophobic channel, in an arrangement that place strong charges next to the tyrosyl radical, reducing its radical lifetime. Differently, flurbiprofen establish a canonical salt bridge with Arg120, with the hydrophobic phenyl ring near the hydroxyl group with low radical perturbation but high binding affinity [67]. Thus, the inhibition of COX-1 can be achieved by high-affinity protein-ligand complexes, as observed by $\mathbf{3 i}, \mathbf{3} \mathbf{m}$ and $\mathbf{3 p}$, in the canonical way [67].

To confirm the hypothesis that thiourea $\mathbf{3 d}$ is able to perturb the dynamics of the tyrosyl radical formation, we evaluated other stable poses of this compound in the active site of COX-1, based on its lower stability in comparison to other active molecules. The second most stable cluster of thiourea $\mathbf{3 d}$ in COX-1 presented the same number of conformations as the most stable one, but with a lower affinity (Binding energy $=-3.52 \mathrm{kcal} / \mathrm{mol}$ ). Such binding mode reveals greater proximity of the thiourea moiety towards Tyr385 hydroxyl group (from 3.7 to $3.4 \AA$ ) in a range of poses that are stabilized by a $2.1 \AA$ hydrogen bound with Gly526, while maintaining the hydrophobic contacts of the phenyl ring (Figure 6). This data corroborates the antiplatelet profile of compound 3d and also confirm the hypothesis that the activity profile of $\mathbf{3 d}$ arises from its modulatory effect onTyr385. In addition these results corroborate with the $\mathrm{Wu}$ et al. studies, revealing the feasibility of a different mechanism of action on COX-1 for molecules that are able to display a non-canonical binding mode to COX-1 [67]. These data reinforce the relevance of novel $N, N^{\prime}$-disubstituted thiourea derivatives as non-anionic antiplatelet agents. 


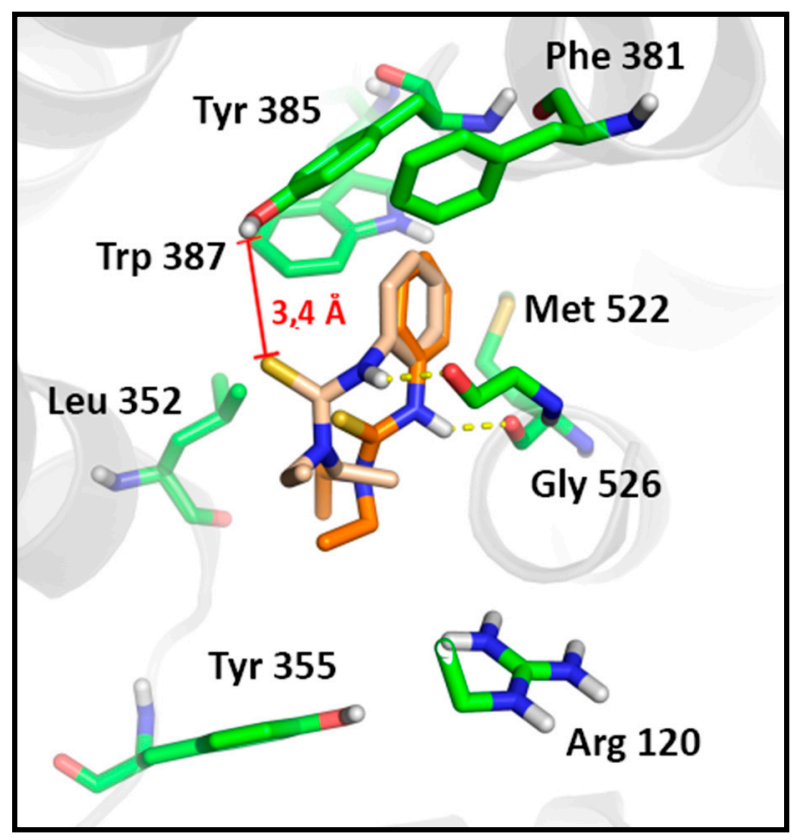

Figure 6. Comparison of the different stable poses observed for the antiplatelet $N, N^{\prime}$-disubstituted thiourea derivative (3d) on COX-1. The most stable pose of the first cluster (Orange, Binding Energy $=-3.79$ ) in comparison to the most stable pose of the second cluster (Pink, Binding Energy = -3.52). Hydrogen bounds are shown as yellow dashes.

Several non-anionic COX-1 inhibitors were recently described with $\mathrm{IC}_{50}$ values ranging from micromolar concentrations ( $26 \mu \mathrm{M}$-rofecoxib, $15 \mu \mathrm{M}$-celecoxib, $0.8 \mu \mathrm{M}$-TFAP) to nanomolar concentrations as biphenyl analogues of sulindac $(570 \mathrm{nM})$ [18]. However even some of those high-selectivity inhibitors may have off-target effects, as described by sulindac derivatives. The series of thiourea derivatives described herein presents new active antiplatelet compounds with $\mathrm{IC}_{50}$ values at a micromolar ranging from 29 to $84 \mu \mathrm{M}$, with no traces of hemolytic or genotoxic activity and no crosslink activity at the plasmatic coagulation cascade. Therefore, we reinforce the potential of the thiourea moiety as a promising pharmacophore for the design of high-selective and safe NSAIDs.

\section{Experimental Section}

\subsection{General Information}

All chemicals were obtained from commercial suppliers and were used without further purification. ${ }^{1} \mathrm{H}$ - and ${ }^{13} \mathrm{C}$-NMR spectra were recorded on an Avance $200 \mathrm{MHz}$ spectrometer (Bruker, Billerica, MA, USA) using $\mathrm{CDCl}_{3}$ or DMSO- $d_{6}$ as the solvent. Standard Bruker software was used throughout. Chemical shifts were given in ppm $(\delta$ scale) and coupling constants $(J)$ were given in hertz $(\mathrm{Hz})$. The IR spectra were obtained on a IRPrestige-21 FTIR spectrometer (Shimadzu, Tokyo, Japan) using $\mathrm{KBr}$ pellets. High-resolution mass spectra (HRMS) were obtained on a Bruker microTOF II mass spectrometer using ESI. Melting points were recorded on a Shimadzu DSC-60 thermal analyzer at a heating rate of $10{ }^{\circ} \mathrm{C} / \mathrm{min}$, room temperature to $200{ }^{\circ} \mathrm{C}$, under a nitrogen flow rate of $50 \mathrm{~mL} / \mathrm{min}$ and using an aluminum standard. Analytical TLC (silica gel, aluminum sheets 60 F254, Merck, Darmstadt, Germany) was performed using ethyl acetate/hexane $(1: 5 \mathrm{v} / \mathrm{v})$ as the eluent. 
General Procedure for the Preparation of Thioureas $\mathbf{3 a}-\mathbf{q}$

To a solution of isothiocyanate $1(1.0 \mathrm{mmol})$ in THF or tert-butanol $(10 \mathrm{~mL})$ was added the appropriate amine $2(1.2 \mathrm{mmol})$. The mixture was stirred at room temperature or refluxed. After the reaction was completed (TLC), the solvent was evaporated and $\mathrm{CH}_{2} \mathrm{Cl}_{2}(10 \mathrm{~mL})$ was added. The organic phase was washed with $5 \% \mathrm{HCl}_{(\mathrm{aq})}(3 \times 10 \mathrm{~mL})$, dried with anhydrous $\mathrm{Na}_{2} \mathrm{SO}_{4}$ and evaporated to dryness to afford the pure product $\mathbf{3}$, which did not require any purification.

$N$-Methyl-N'-phenylthiourea (3a) [68]. White solid; mp 115-117 ${ }^{\circ} \mathrm{C}$ (Lit. [68] 110-112 $\left.{ }^{\circ} \mathrm{C}\right)$; IR (KBr): 3263, 3161, 2989, 1595, 1541, 1519, 1255, 1033, 725, $690 \mathrm{~cm}^{-1} ;{ }^{1} \mathrm{H}-\mathrm{NMR}\left(\mathrm{CDCl}_{3}\right) \delta 8.28$ (br s, $\left.1 \mathrm{H}\right)$, 7.47-7.38 (m, 2H), 7.34-7.21 (m, 3H), 6.12 (br s, $1 \mathrm{H}), 3.11(\mathrm{~d}, J=4.7 \mathrm{~Hz}, 3 \mathrm{H}) ;{ }^{13} \mathrm{C}-\mathrm{NMR}\left(\mathrm{CDCl}_{3}\right)$ $\delta 181.7,136.4,130.3,127.4,125.5,32.2$; HRMS-ESI: $m / z[\mathrm{M}+\mathrm{Na}]^{+}$calculated for $\mathrm{C}_{8} \mathrm{H}_{10} \mathrm{~N}_{2} \mathrm{~S}: 189.0457$; found: 189.0465 .

$N$-Cyclohexyl-N'-phenylthiourea (3b) [69]. White solid; mp $149-151{ }^{\circ} \mathrm{C}$ (Lit. [69] $144-145{ }^{\circ} \mathrm{C}$ ); IR (KBr): 3269, 3240, 2937, 2852, 1541, 1508, 1450, 1147, $983 \mathrm{~cm}^{-1} ;{ }^{1} \mathrm{H}-\mathrm{NMR}\left(\mathrm{CDCl}_{3}\right) \delta 8.12$ (br s, $\left.1 \mathrm{H}\right)$, $7.43(\mathrm{t}, J=7.6 \mathrm{~Hz}, 2 \mathrm{H}), 7.32-7.18(\mathrm{~m}, 3 \mathrm{H}), 5.94(\mathrm{br} \mathrm{d}, 1 \mathrm{H}), 4.39-4.14(\mathrm{~m}, 1 \mathrm{H}), 2.14-2.02(\mathrm{~m}, 2 \mathrm{H})$, 1.79-1.63 (m, 3H), 1.49-1.30 (m, 2H), 1.24-1.03 (m, 3H); ${ }^{13} \mathrm{C}-\mathrm{NMR}\left(50 \mathrm{MHz}, \mathrm{CDCl}_{3}\right) \delta 179.3,136.4$, 130.4, 127.2, 125.1, 54.1, 32.7, 25.6, 24.8; HRMS-ESI: $m / z[\mathrm{M}+\mathrm{Na}]^{+}$calculated for $\mathrm{C}_{13} \mathrm{H}_{18} \mathrm{~N}_{2} \mathrm{~S}$ : 257.1083; found: 257.1088 .

$N$-(2-Hydroxyethyl)-N'-phenylthiourea (3c) [70]. White solid; mp 139-141 ${ }^{\circ} \mathrm{C}$; IR (KBr): 3361, 3184, 3001, 2949, 1544, 1253, 1056, 929, $690 \mathrm{~cm}^{-1}$; ${ }^{1} \mathrm{H}-\mathrm{NMR}$ (DMSO-d6) $\delta 9.60$ (br s, 1H), 7.70 (br s, 1H), 7.47-7.42 (m, 2H), 7.35-7.27 (m, 2H), 7.14-7.05 (m, 1H), 4.82 (br s, 1H), 3.56-3.54 (m, 4H); ${ }^{13} \mathrm{C}-\mathrm{NMR}$ $\left(50 \mathrm{MHz}, \mathrm{DMSO}-d_{6}\right) \delta 180.5,139.3,128.5,124.0,123.0,59.3,46.4$; HRMS-ESI: $m / z[\mathrm{M}+\mathrm{Na}]^{+}$ calculated for $\mathrm{C}_{9} \mathrm{H}_{12} \mathrm{~N}_{2} \mathrm{OS}: 219.0562$; found: 219.0563 .

$N$-N-Diethyl-N'-phenylthiourea (3d). Yellow oil; IR (film): 3259, 2975, 2931, 2084, 1596, 1525, 1376, 1350, 1137, 1095, 761, $698 \mathrm{~cm}^{-1},{ }^{1} \mathrm{H}-\mathrm{NMR}\left(\mathrm{CDCl}_{3}\right) \delta 7.35-7.24(\mathrm{~m}, 4 \mathrm{H}), 7.20-7.11(\mathrm{~m}, 1 \mathrm{H}), 7.02$ (br s, 1H), 3.69 (q, $J=7.1 \mathrm{~Hz}, 4 \mathrm{H}), 1.25(\mathrm{t}, J=7.1 \mathrm{~Hz}, 6 \mathrm{H}) ;{ }^{13} \mathrm{C}-\mathrm{NMR}\left(\mathrm{CDCl}_{3}\right) \delta 180.9,139.9,128.7,125.9$, 125.8, 45.8, 12.8; HRMS-ESI: $\mathrm{m} / z$ [M+Na $]^{+}$calculated for $\mathrm{C}_{11} \mathrm{H}_{16} \mathrm{~N}_{2} \mathrm{~S}: 231.0926$; found: 231.0932 .

$N$-Phenyl-N'-(3,4,5-trimethoxyphenyl)thiourea (3e). White solid; mp 164-166 ${ }^{\circ} \mathrm{C}$; IR (KBr): 3278, 3159 , 2999, 2941, 1597, 1537, 1506, 1255, 1134, 997, $696 \mathrm{~cm}^{-1} ;{ }^{1} \mathrm{H}-\mathrm{NMR}\left(\mathrm{CDCl}_{3}\right) \delta 8.05$ (br s, 2H), $7.42-7.37(\mathrm{~m}, 4 \mathrm{H}), 7.34-7.20(\mathrm{~m}, 1 \mathrm{H}), 6.63(\mathrm{~s}, 2 \mathrm{H}), 3.84(\mathrm{~s}, 9 \mathrm{H}) ;{ }^{13} \mathrm{C}-\mathrm{NMR}\left(\mathrm{CDCl}_{3}\right) \delta 180.0,153.9$, 137.4, 137.2, 132.7, 129.6, 127.1, 125.3, 103.3, 61.1, 56.5; HRMS-ESI: $m / z[\mathrm{M}+\mathrm{Na}]^{+}$calculated for $\mathrm{C}_{16} \mathrm{H}_{18} \mathrm{~N}_{2} \mathrm{O}_{3} \mathrm{~S}$ : 341.0930; found: 341.0940.

$N-3,4-$ Methylenedioxyphenyl-N'-phenylthiourea (3f). Dark solid; mp 140-142 ${ }^{\circ} \mathrm{C}$; IR (KBr): 3325,3161 , 2957, 1547, 1501, 1485, 1373, 1034, 926, 743, $694 \mathrm{~cm}^{-1} ;{ }^{1} \mathrm{H}-\mathrm{NMR}\left(\mathrm{CDCl}_{3}\right) \delta 8.18-7.83(\mathrm{~m}, 2 \mathrm{H})$, 7.56-7.17 (m, 5H), 6.99-6.65 (m, 3H), $5.98(\mathrm{~s}, 2 \mathrm{H}) ;{ }^{13} \mathrm{C}-\mathrm{NMR}\left(\mathrm{CDCl}_{3}\right) \delta 180.6,148.5,147.1,137.4$, $130.8,129.6,127.1,125.4,119.7,108.7,107.8,102.0$; HRMS-ESI: $m / z[\mathrm{M}+\mathrm{Na}]^{+}$calculated for $\mathrm{C}_{14} \mathrm{H}_{12} \mathrm{~N}_{2} \mathrm{O}_{2} \mathrm{~S}: 295.0512$; found: 295.0520 . 
$N$ - $\alpha$-Naphthyl-N'-phenylthiourea (3g) [71]. White solid; mp $155-157{ }^{\circ} \mathrm{C}$ (Lit. [71] 162-163 ${ }^{\circ} \mathrm{C}$ ); IR (KBr): 3339, 3134, 2965, 1593, 1537, 1506, 1395, 1275, 1221, 775, 696, $646 \mathrm{~cm}^{-1}$; ${ }^{1} \mathrm{H}-\mathrm{NMR}$ (DMSO-d6) $\delta 9.96$ (br s, 2H), 8.06-7.91 (m, 2H), 7.88-7.82 (m, 1H), 7.65-7.48 (m, 6H), 7.40-7.29 (m, 2H), 7.16-7.08 (m, 1H); ${ }^{13} \mathrm{C}-\mathrm{NMR}$ (DMSO-d6) $\delta 181.3,139.7,135.2,133.9,129.9,128.4,128.3,128.1$, 126.1 , 126.0, 125.6, 124.4, 123.9, 123.6, 123.1; HRMS-ESI: $m / z[\mathrm{M}+\mathrm{Na}]^{+}$calculated for $\mathrm{C}_{17} \mathrm{H}_{14} \mathrm{~N}_{2} \mathrm{~S}$ : 301.0770; found: 301.0775 .

$N$-Benzyl-N'-isopropylthiourea (3h) [72]. Pale yellow solid; mp 121-123 ${ }^{\circ} \mathrm{C}$ (Lit. [72], 122-123 ${ }^{\circ} \mathrm{C}$ ); IR (KBr): 3363, 3145, 2974, 1539, 1298, 972, 744, $640 \mathrm{~cm}^{-1}$; ${ }^{1} \mathrm{H}-\mathrm{NMR}\left(\mathrm{CDCl}_{3}\right) \delta 7.51-7.24(\mathrm{~m}, 5 \mathrm{H}), 6.31$ (br s, 1H), 5.91 (br s, 1H), $4.60(\mathrm{~d}, J=5.2 \mathrm{~Hz}, 2 \mathrm{H}), 4.29-4.07(\mathrm{~m}, 1 \mathrm{H}), 1.14(\mathrm{~d}, J=6.5 \mathrm{~Hz}, 6 \mathrm{H})$; ${ }^{13} \mathrm{C}-\mathrm{NMR}\left(\mathrm{CDCl}_{3}\right) \delta 180.9,137.2,129.0,128.0,127.7,48.5,46.4,22.6$; HRMS-ESI: $m / z$ [M+Na] ${ }^{+}$ calculated for $\mathrm{C}_{11} \mathrm{H}_{16} \mathrm{~N}_{2} \mathrm{~S}$ : 231.0926; found: 231.0926.

$N$-Benzyl-N',N'-diethylthiourea (3i) [73]. Yellowoil; IR (film): 3312, 2975, 2930, 1532, 1441, 1347, 1280, 1136, 862, $698 \mathrm{~cm}^{-1} ;{ }^{1} \mathrm{H}-\mathrm{NMR}\left(\mathrm{CDCl}_{3}\right) \delta 7.46-7.22(\mathrm{~m}, 5 \mathrm{H}), 5.55$ (br s, $\left.1 \mathrm{H}\right), 4.87(\mathrm{~d}, J=4.9 \mathrm{~Hz}$, 2H), $3.66(\mathrm{q}, J=7.1 \mathrm{~Hz}, 4 \mathrm{H}), 1.23(\mathrm{t}, J=7.1 \mathrm{~Hz}, 6 \mathrm{H}) ;{ }^{13} \mathrm{C}-\mathrm{NMR}\left(\mathrm{CDCl}_{3}\right) \delta 180.6,138.4,128.9,128.0$, 127.7, 50.3, 45.3, 12.8; HRMS-ESI: $m / z$ [M+Na] $]^{+}$calculated for $\mathrm{C}_{12} \mathrm{H}_{18} \mathrm{~N}_{2} \mathrm{~S}: 245.1083$; found: 245.1077.

N-Benzyl-N'-(3,4-methylenedioxyphenyl)thiourea (3j). Dark solid; mp 114-116 ${ }^{\circ} \mathrm{C}$; IR (KBr): 3317 , 3161, 3005, 1546, 1523, 1487, 1246, 1197, 1039, 923, $700 \mathrm{~cm}^{-1} ;{ }^{1} \mathrm{H}-\mathrm{NMR}\left(\mathrm{CDCl}_{3}\right) \delta 8.06$ (br s, $\left.1 \mathrm{H}\right)$, 7.54-7.18 (m, 5H), 6.91-6.63 (m, 3H), 6.23 (br s, 1H), 5.97 (s, 2H), $4.84(\mathrm{~d}, J=5.4 \mathrm{~Hz}, 2 \mathrm{H}) ;{ }^{13} \mathrm{C}-\mathrm{NMR}$ $\left(\mathrm{CDCl}_{3}\right) \delta 181.6,148.9,147.3,137.6,129.7,128.9,127.8,127.7,119.9,109.1,107.6,102.0,49.5$; HRMS-ESI: $m / z$ [M+Na] $]^{+}$calculated for $\mathrm{C}_{15} \mathrm{H}_{14} \mathrm{~N}_{2} \mathrm{O}_{2} \mathrm{~S}: 309.0668$; found: 309.0667 .

$N$-Isopropyl-N'-(2-phenethyl)thiourea (3k). White solid; mp 126-128 ${ }^{\circ} \mathrm{C}$; IR (KBr): 3298, 3234, 2971, 2922, 2360, 2333, 1564, 1519, 1183, 1003, 773, $694 \mathrm{~cm}^{-1}$; ${ }^{1} \mathrm{H}-\mathrm{NMR}\left(\mathrm{CDCl}_{3}\right) \delta$ 7.37-7.15 (m, 5H), 5.79 (br $\mathrm{s}, 2 \mathrm{H}), 4.12-3.87(\mathrm{~m}, 1 \mathrm{H}), 3.71(\mathrm{q}, J=6.6 \mathrm{~Hz}, 2 \mathrm{H}), 2.92(\mathrm{t}, J=6.6 \mathrm{~Hz}, 2 \mathrm{H}), 1.15(\mathrm{~d}, J=6.4 \mathrm{~Hz}, 6 \mathrm{H})$; ${ }^{13} \mathrm{C}-\mathrm{NMR}\left(\mathrm{CDCl}_{3}\right) \delta 180.7,138.6,129.0,128.9,126.9,46.0,45.8,35.4,22.6$; HRMS-ESI: $\mathrm{m} / z[\mathrm{M}+\mathrm{Na}]^{+}$ calculated for $\mathrm{C}_{12} \mathrm{H}_{18} \mathrm{~N}_{2} \mathrm{~S}$ : 245.1083; found: 245.1082 .

$N$-Butyl-N'-(2-phenethyl)thiourea (3I). Pale yellow solid; mp $61-63{ }^{\circ} \mathrm{C}$; IR (KBr): 3253, 2958, 2933, 2361, 1568, 1434, 1408, 1246, 1186, 1094, 1003, $977 \mathrm{~cm}^{-1} ;{ }^{1} \mathrm{H}-\mathrm{NMR}\left(\mathrm{CDCl}_{3}\right) \delta 7.37-7.20$ (m, 5H), 5.94 (br s, 1H), 5.79 (br s, 1H), 3.77 (q, $J=6.5 \mathrm{~Hz}, 2 \mathrm{H}), 3.24-3.22(\mathrm{~m}, 2 \mathrm{H}), 2.92(\mathrm{t}, J=6.5,2 \mathrm{H}), 1.59-1.42$ $(\mathrm{m}, 2 \mathrm{H}), 1.38-1.23(\mathrm{~m}, 2 \mathrm{H}), 0.90(\mathrm{t}, J=7.1 \mathrm{~Hz}, 3 \mathrm{H}) ;{ }^{13} \mathrm{C}-\mathrm{NMR}\left(\mathrm{CDCl}_{3}\right) \delta 181.7,138.6,128.9(2 \mathrm{C})$, 126.9, 45.9, 43.9, 35.4, 31.0, 20.2, 13.8; HRMS-ESI: $m / z[\mathrm{M}+\mathrm{Na}]^{+}$calculated for $\mathrm{C}_{13} \mathrm{H}_{20} \mathrm{~N}_{2} \mathrm{~S}: 259.1239$; found: 259.1242 .

$N, N$-diethyl-N'-(2-phenethyl)thiourea (3m) [74]. White solid; mp 72-74 ${ }^{\circ} \mathrm{C}$ (Lit. [74] 67-69 $\left.{ }^{\circ} \mathrm{C}\right)$; IR (KBr): 3393, 2930, 2360, 2332, 1541, 1453, 1410, 1330, 1269, 1135, $756 \mathrm{~cm}^{-1} ;{ }^{1} \mathrm{H}-\mathrm{NMR}\left(\mathrm{CDCl}_{3}\right) \delta$ $7.35-7.20(\mathrm{~m}, 5 \mathrm{H}), 5.33$ (br s, 1H), 3.90 (q, $J=6.5 \mathrm{~Hz}, 2 \mathrm{H}), 3.54$ (q, $J=7.1 \mathrm{~Hz}, 4 \mathrm{H}), 2.96$ (t, $J=6.5 \mathrm{~Hz}$, 2H), $1.09(\mathrm{t}, J=7.1 \mathrm{~Hz}, 6 \mathrm{H}) ;{ }^{13} \mathrm{C}-\mathrm{NMR}\left(\mathrm{CDCl}_{3}\right) \delta 180.3,139.1,128.9,128.8,126.7,46.8,45.1,35.2$, 12.6; HRMS-ESI: $m / z[\mathrm{M}+\mathrm{Na}]^{+}$calculated for $\mathrm{C}_{13} \mathrm{H}_{20} \mathrm{~N}_{2} \mathrm{~S}$ : 259.1239; found: 259.1232. 
N-Cyclohexyl-N'-(2-phenethyl)thiourea (3n). Pale yellow solid; mp 109-111 ${ }^{\circ} \mathrm{C}$; IR (KBr): 3289, 3224, 3047, 2930, 2856, 1547, 1319, 1193, 1123, 1058, $713 \mathrm{~cm}^{-1} ;{ }^{1} \mathrm{H}-\mathrm{NMR}\left(\mathrm{CDCl}_{3}\right) \delta 7.36-7.12(\mathrm{~m}, 5 \mathrm{H}), 5.89$ (br s, 2H), 3.77-3.68 (m, 3H), $2.91(\mathrm{t}, J=7.0 \mathrm{~Hz}, 2 \mathrm{H}), 1.98-1.57(\mathrm{~m}, 5 \mathrm{H}), 1.44-0.98(\mathrm{~m}, 5 \mathrm{H}) ;{ }^{13} \mathrm{C}-\mathrm{NMR}$ $\left(\mathrm{CDCl}_{3}\right) \delta 180.4,138.6,128.9(2 \mathrm{C}), 126.8,52.9,45.7,35.3,32.8,25.4,24.8$; HRMS-ESI: $m / z$ [M+Na] ${ }^{+}$ calculated for $\mathrm{C}_{15} \mathrm{H}_{22} \mathrm{~N}_{2} \mathrm{~S}$ : 285.1396; found: 285.1396 .

$N$-( $\alpha$-Naphthyl)-N'-(2-phenethyl)thiourea (3o). White solid;mp $155-157{ }^{\circ} \mathrm{C}$; IR (KBr): 3364, 3314, 3309, 2362, 1596, 1537, 1495, 1342, 1266, 1013, 772, $696 \mathrm{~cm}^{-1} ;{ }^{1} \mathrm{H}-\mathrm{NMR}\left(\mathrm{CDCl}_{3}\right) \delta 8.34$ (br s, 1H), 8.05-7.80 (m, 3H), 7.60-7.46 (m, 2H), 7.43-7.35 (m, 1H), 7.25-7.19 (m, 1H), 7.11-7.00 (m,3H), 6.93-6.86 (m, 2H), $5.66(\mathrm{br} \mathrm{s}, 1 \mathrm{H}), 3.77$ (q, $J=6.6 \mathrm{~Hz}, 2 \mathrm{H}), 2.75(\mathrm{t}, J=6.6 \mathrm{~Hz}, 2 \mathrm{H}) ;{ }^{13} \mathrm{C}-\mathrm{NMR}\left(\mathrm{CDCl}_{3}\right)$ $\delta 181.4,138.2,134.6,131.5,130.0,128.8,128.5,128.4,128.3,127.4,127.0,126.4,125.6,125.2,122.5$, 46.2, 34.8; HRMS-ESI: $m / z$ [M+Na] ${ }^{+}$calculated for $\mathrm{C}_{19} \mathrm{H}_{18} \mathrm{~N}_{2} \mathrm{~S}$ : 329.1083 ; found: 329.1074 .

$N-(3,4-M e t h y l e n e d i o x y p h e n y l)-N$-(2-phenethyl)thiourea (3p). Dark solid; mp 126-128 ${ }^{\circ} \mathrm{C}$; IR (KBr): 3305, 3196, 3026, 1548, 1535, 1500, 1487, 1244, 1037, 931, $858 \mathrm{~cm}^{-1} ;{ }^{1} \mathrm{H}-\mathrm{NMR}\left(\mathrm{CDCl}_{3}\right) \delta 7.89$ (br s, $1 \mathrm{H}), 7.42-7.07(\mathrm{~m}, 5 \mathrm{H}), 6.69(\mathrm{~d}, J=7.9 \mathrm{~Hz}, 1 \mathrm{H}), 6.52-6.47(\mathrm{~m}, 2 \mathrm{H}), 5.99(\mathrm{~s}, 2 \mathrm{H}), 5.87$ (br s, $1 \mathrm{H}), 3.84$ $(\mathrm{q}, J=6.6 \mathrm{~Hz}, 2 \mathrm{H}), 2.90(\mathrm{t}, J=6.6 \mathrm{~Hz}, 2 \mathrm{H}) ;{ }^{13} \mathrm{C}-\mathrm{NMR}\left(\mathrm{CDCl}_{3}\right) \delta 181.1,148.8,147.2,138.6,129.5$, 128.9, 128.8, 126.8, 119.8, 109.0, 107.5, 102.0, 46.3, 35.0; HRMS-ESI: $m / z[\mathrm{M}+\mathrm{Na}]^{+}$calculated for $\mathrm{C}_{16} \mathrm{H}_{16} \mathrm{~N}_{2} \mathrm{O}_{2} \mathrm{~S}: 323.0825$; found: 323.0832 .

$N$-(3,4-Methylenedioxyphenyl)-N'-(3,4,5-trimethoxyphenyl)thiourea (3q). Dark solid; mp 142-144 ${ }^{\circ} \mathrm{C}$; IR (KBr): 3313, 3196, 2999, 2835, 1600, 1541, 1236, 1124, 1033, $995 \mathrm{~cm}^{-1} ;{ }^{1} \mathrm{H}-\mathrm{NMR}\left(\mathrm{CDCl}_{3}\right) \delta 8.04$ (br s, 2H), 6.93-6.92 (m, 1H), 6.79-6.77 (m, 2H), $6.63(\mathrm{~s}, 2 \mathrm{H}), 5.99(\mathrm{~s}, 2 \mathrm{H}), 3.83-3.82(\mathrm{~m}, 9 \mathrm{H})$; ${ }^{13} \mathrm{C}-\mathrm{NMR}\left(\mathrm{CDCl}_{3}\right) \delta 180.4,153.8,148.4,146.9,137.0,132.9,131.0,119.5,108.6,107.7,103.2,101.9$, 61.0, 56.4; HRMS-ESI: $m / z$ [M+Na] ${ }^{+}$calculated for $\mathrm{C}_{17} \mathrm{H}_{18} \mathrm{~N}_{2} \mathrm{O}_{5} \mathrm{~S}: 385.0829$; found: 385.0826 .

\subsection{Pharmacology}

\subsubsection{Platelet Aggregation Assays}

The human blood samples were obtained from adult volunteers, who abstained from the use of drugs or other substances that could interfere with the experiment for at least 15 days prior. Local ethical committee approved the procedure under protocol 140/10 and 177/11. The platelet rich (PRP) and poor (PPP) plasma were prepared by differential centrifugation and platelet aggregation was monitored using the turbidimetric method described by Born and Cross with an aggregometer 4-Pack ${ }^{\circledR}$ (Helena Laboratories, Beaumount, TX, USA) [75]. Different concentrations of the synthetic derivatives and the vehicle (DMSO 1\%) were pre-incubated for $2 \mathrm{~min}$ before addition of the agonists $(500 \mu \mathrm{M}$ arachidonic acid and $5 \mu \mathrm{g} / \mathrm{mL}$ collagen). The platelet aggregation tests were performed in triplicate and the data were statistically analyzed $[76,77]$. The concentration capable of inhibiting $50 \%$ of platelet aggregation was obtained through non-linear regression of the dose-response curve obtained for each compound $(0,10$, 50 and $100 \mu \mathrm{M}$ ) performed in Matlab version 2014 (Mathworks $^{\circledR}$, Natick, MA, USA) with R $^{2}=0.99$. 


\subsubsection{Clotting Assay}

For tests of activated partial thromboplastin time (aPTT) and Prothrombin Time (PT) donor citrated plasma samples were obtained from Antônio Pedro University Hospital (pool $=6$ donors). No disturbances to the hemostatic system were found, and the international normalized ratio (INR was expressed for coagulation less than or equal to 1.3. Assays were performed using the coagulation analyzer CoagLab ${ }^{\circledR}$ IV (Beijing Shining Sun Technology Co., Ltd., Beijing, China) as described by described by Sathler et al. [44].

\subsubsection{Measurement of Plasma $\mathrm{TXB}_{2}$ Levels}

Plasma samples containing $100 \mu \mathrm{M}$ of each thiourea with antiplatelet activity were used to determine the concentrations of thromboxane $\mathrm{B}_{2}$, an index of in vitro COX-1 activity [78]. Briefly, $10 \mu \mathrm{L}$ of arachidonic acid $(500 \mu \mathrm{M})$ were added to platelet-rich plasma samples containing each active derivative $(100 \mu \mathrm{M})$ under stir conditions. After five minutes the suspensions were mixed with $3 \mu \mathrm{L}$ Indomethacin $(10 \mathrm{mM})$ stop-solution. By sonication for $15 \mathrm{~min}$, platelets were disrupted, and the resulting homogenates were centrifuged at $2000 \mathrm{~g}$ for $10 \mathrm{~min}$ to allow complete release of TXB2. Plasma levels of TXB $\mathrm{TXe}_{2}$ measured in duplicate by competitive immunoassay using commercially available kits from EIA Cayman ( $\mathrm{TXB}_{2}$ EIA Kit, Cayman Chemical Co, Ann Arbor, MI, USA) according to the manufacturer's instructions. A threshold of $25.75 \mathrm{ng} / \mathrm{mL}$ was defined as control plasma levels of TXB 2 after platelet disrupture.

\subsubsection{Measurement of Plasma $\mathrm{PGE}_{2}$ Levels}

Plasma samples containing $100 \mu \mathrm{M}$ of each thiourea with antiplatelet activity were used to determine the concentrations of prostaglandin $\mathrm{H}_{2}$, an index of in vitro COX-1 activity [78]. Briefly, ozagrel ( $3 \mu \mathrm{L}$, $100 \mu \mathrm{M})$ were added to stop TXS activity and the aggregation were triggered with $10 \mu \mathrm{L}$ of arachidonic acid $(500 \mu \mathrm{M})$ in PRP samples containing each active derivative $(100 \mu \mathrm{M})$ under stir conditions. After five minutes the suspensions were mixed with indomethacin $(3 \mu \mathrm{L}, 10 \mathrm{mM})$ stop-solution. By sonication for $1 \mathrm{~min}$, platelets were disrupted and purification step were performed according to the manufacturer's instructions (Cayman Chemical Co.). Plasma levels of PGE2 were measured in duplicate by competitive immunoassay using commercially available kits for EIA (PGE2 EIA Kit, Cayman Chemical Co.) according to the manufacturer's instructions. A threshold of $25.75 \mathrm{ng} / \mathrm{mL}$ was defined as control plasma levels of PGE2 after platelet disrupture.

\subsubsection{Hemolysis Assay}

Healthy erythrocytes were washed three times with PBS ( $\mathrm{pH} 7.4$ ) by centrifugation and suspended in the same buffer. All derivatives were incubated with the erythrocyte suspension for $3 \mathrm{~h}$ at $37{ }^{\circ} \mathrm{C}$. The release of hemoglobin was determined by monitoring the optical density of the supernatant at $540 \mathrm{~nm}$. The experiments were performed in triplicate and complete hemolysis (positive control) was determined using 1\% Triton X-100. Hemolysis less than 10\% indicated good hemocompatibility and non-toxicity of the molecules tested $[48,79,80]$. 


\subsubsection{Reverse Mutagenesis to Histidine Prototrophy (Ames Test)—“Spot Test”}

This assay was performed as described by Maron and Ames [81], using the histidine Salmonella typhimurium auxotroph mutant strains TA97, TA98, TA100 and the wild type strain TA102 (Table 5). Each assay was conducted in duplicate and the results obtained show a comparison between the thiourea derivatives and the positive control 4-NQO. The negative results indicated that the thiourea derivatives have no mutagenic properties $[81,82]$.

Table 5. Strains of Salmonella typhimurium used in the reverse mutagenesis to histidine prototrophy (Ames test)—_'Spot test".

\begin{tabular}{|c|c|}
\hline Designations & Relevant Genotype \\
\hline TA97 & 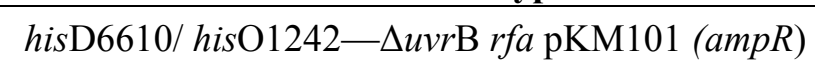 \\
\hline TA98 & his $\mathrm{D} 3052-\Delta u v r \mathrm{~B} r f a \mathrm{pKM} 101(\operatorname{amp} \mathrm{R})$ \\
\hline TA100 & hisG46- $\Delta u v r \mathrm{~B} r f a \mathrm{pKM} 101(\operatorname{ampR})$ \\
\hline TA102 & his G428-wild type rfapKM101( $a m p \mathrm{R}) \mathrm{pAQ} 1$ (tet $\mathrm{R})$ \\
\hline
\end{tabular}

\subsubsection{SOS Chromotest-“Spot Test"}

The SOS chromotest (spot test) was performed according to Quillardet and Hofnung [53], using Escherichia coli (Table 6) strains PQ35 and PQ37. One hundred microliters of an overnight culture of the $E$. coli strains are diluted in $5 \mathrm{~mL}$ of LB medium and the culture is incubated at $37^{\circ} \mathrm{C}$ in a gyratory incubator up to a concentration of $2 \times 10^{8}$ bacteria/mL. Fractions of $0.1 \mathrm{~mL}$ of the culture are then distributed into test tube with top agar, and the mixture is poured immediately on M63 medium plate. A sample of $10 \mu \mathrm{L}$ of the thiourea derivatives is spotted onto the center of the plate. After overnight incubation at $37^{\circ} \mathrm{C}$, the presence of a blue ring around a zone of inhibition indicates genotoxic activity. Each assay was conducted in triplicate and the results obtained show a comparison between the thiourea derivatives and the positive control 4-NQO.

Table 6. Strains of Escherichia coli used in SOS chromotest—“Spot test".

\begin{tabular}{|c|c|c|}
\hline Designations & Critical Markers & Other Markers \\
\hline PQ35 & $\begin{array}{c}\text { sfiA:: } \operatorname{Mud(Aplac)cts} \\
\text { lac } \Delta \mathrm{U} 169 \\
\mathrm{mal}^{+}, \text {uvr }^{+}, \text {galEgalY, PhoC, } r f a\end{array}$ & $\begin{array}{c}\text { Same markers as GC4436 } \\
\qquad r p o B\end{array}$ \\
\hline PQ37 & $\begin{array}{c}\text { sfiA::Mud(Aplac) cts } \\
\text { lac } \Delta \mathrm{U} 169 \\
\mathrm{mal}^{+}, \text {uvrA } \text {, galEgalY, PhoC, rfa }\end{array}$ & $\begin{array}{l}\text { Same markers as GC4436 } \\
r p o B\end{array}$ \\
\hline
\end{tabular}

\subsection{Molecular Modeling}

\section{SAR and Docking Studies}

All molecular computations were performed using SPARTAN'10 (Wavefunction Inc. Irvine, CA, USA) as described elsewhere [77,83-85]. Briefly, the structures were optimized to a local minimum and the equilibrium geometry was obtained in a vacuum using RM1 semi empirical methods. Subsequently, 
molecules were submitted to a single-point energy ab initio calculation, at the 6-31G** level, to calculate some stereoelectronic properties and to perform SAR studies. Thus, we calculated HOMO and LUMO energies and isosurface density, molecular weight, molecular surface area, polar surface area, dipole moment, lipophilicity and electrostatic potential maps for all compounds best conformation.

Docking studies were carried on using the ovine COX-1 in complex with indomethacin (PDB ID: 2OYE) crystal structure and a TXS model recently publishes [44]. Briefly, the three-dimensional grid was set over both COX-1 and TXS active site in a $60 \times 60 \times 60 \AA$ grid box with $0.171 \AA$ spacing between points. Ligand torsions were set using the maximum freedom while the protein structure was set as rigid. Grid parameters were generated using the software Autogrid 4.0 available in AutoDock Tools (TSRI ${ }^{\odot}$, La Jolla, CA, USA), molecular docking was performed using the software AutoDock 4.0 with Lamarkian genetic algorithm through 50 generations. Redocking of indomethacin resulted in a stable model with an overall RMSD of $1.7 \AA$ to the crystallographic pose, prompting the usage of this method for further studies with thiourea derivatives [86,87].

\section{Conclusions}

In this work we present a series of $N, N^{\prime}$-disubstituted thioureas $3 \mathbf{a}-\mathbf{q}$ that were designed and synthesized in high yields $(82 \%-97 \%)$ as non-anionic antiplatelet agents against the arachidonic acid platelet aggregation pathway. The most active antiplatelet agents (compounds $\mathbf{3 d}, \mathbf{3 i}, \mathbf{3 m}$ and $\mathbf{3 p}$ ) were able to reduce both $\mathrm{PGE}_{2}$ and $\mathrm{TXB}_{2}$ production in human platelets, suggesting a direct inhibition of COX-1. Structural features such as hydrophobicity, chain length and presence of HBA groups were observed as important characteristics for the proposed mechanism of action. This series of compounds shows low mutagenic and genotoxic profiles according to Ames test and SOS chromotest, and good hemocompatibility toward healthy human erythrocyte, which reinforce their promising lead profile as antiplatelet agents for further in vivo experimental investigations.

\section{Supplementary Materials}

Supplementary materials can be accessed at: http://www.mdpi.com/1420-3049/20/04/7174/s1.

\section{Acknowledgments}

We thank the financial support of Fundação de Amparo à Pesquisa do Estado do Rio de Janeiro (FAPERJ), Conselho Nacional de Desenvolvimento Científico e Tecnológico (CNPq) and Coordenação de Aperfeiçoamento de Pessoal Docente (CAPES — Nanobiotec 2008).

\section{Author Contributions}

L.E.G.D., G.M.V., A.G.M.F. and L.C.S.A. were responsible for the preparation of the compounds, identification and purity analysis. A.L.L., M.S.S. and P.C.S. were responsible for biological tests and in silico evaluation. T.F.S.D. and M.P. were responsible for genotoxic and mutagenic assays. The conception and design of this study was performed by H.C.C. and L.M.C., with the collaboration of C.R.R. and V.P.S. in the interpretation and discussing of the results. All authors revised the draft and approved the version submitted. 


\section{Conflicts of Interest}

The authors declare no conflict of interest.

\section{References}

1. De Almeida Chaves, D.S.; Costa, S.S.; de Almeida, A.P.; Frattani, F.; Assafim, M.; Zingali, R.B. Metabólitos secundários de origem vegetal: Uma fonte potencial de fármacos antitrombóticos. Quim Nova 2010, 33, 172-180.

2. Baker, D.C.; Brassard, J. Review of Continuing Education Course on Hemostasis. Toxicol. Pathol. 2011, 39, 281-288.

3. Al Ghumlas, A.K.; Gader, A.G.M.A. The Blood Platelet: An Intriguing Cell. J. Appl. Hematol. 2013, 4, 1-12.

4. Naik, M.U.; Stalker, T.J.; Brass, L.F.; Naik, U.P. JAM-A protects from thrombosis by suppressing integrin $\alpha \operatorname{IIb} \beta 3$-dependent outside-in signaling in platelets. Blood 2012, 119, 3352-3360.

5. Wolberg, A.S.; Aleman, M.M.; Leiderman, K.; Machlus, K.R. Procoagulant activity in hemostasis and thrombosis: Virchow's triad revisited. Anesth. Analg. 2012, 114, 275-285.

6. Kei, A.A.; Florentin, M.; Mikhailidis, D.P.; Elisaf, M.S.; Liberopoulos, E.N. Review: Antiplatelet drugs: What comes next? Clin. Appl. Thromb. Hemost. 2011, 17, 9-26.

7. Angiolillo, D.J.; Datto, C.; Raines, S.; Yeomans, N.D. Impact of concomitant low-dose aspirin on the safety and tolerability of naproxen and esomeprazole magnesium delayed-release tablets in patients requiring chronic nonsteroidal anti-inflammatory drug therapy: An analysis from 5 Phase III studies. J. Thromb. Thrombolysis 2013, 38, 11-23.

8. Choi, J.-T.; Shin, K.-A. and Kim, Y.-K. Prevalence of Aspirin Resistance and Clinical Characteristics in Patients with Cerebral Infarction. Korean Soc. Biomed. Lab. Sci. 2013, 19, 233-238.

9. Kunadian, V.; Sinclair, H.; Sutton, A.; Dangas, G.D. Aspirin, Platelet P2Y12 Receptor Inhibitors, and Other Oral Antiplatelets: Comparative Pharmacology and Role in Elective PCI. Interv. Cardiol. Clin. 2013, 2, 527-535.

10. Shah, R.; Keough, L.A.; Belalcazar-Portacio, A.; Ramanathan, K.B. Ticagrelor as an alternative in clopidogrel-associated neutropenia. Platelets 2014, 26, 80-82.

11. Mattiello, T.; Guerriero, R.; Lotti, L.V.; Trifirò, E.; Felli, M.P.; Barbarulo, A.; Pucci, B.; Gazzaniga, P.; Gaudio, C.; Frati, L.Others Aspirin Extrusion From Human Platelets Through Multidrug Resistance Protein-4-Mediated TransportEvidence of a Reduced Drug Action in Patients After Coronary Artery Bypass Grafting. J. Am. Coll. Cardiol. 2011, 58, 752-761.

12. Floyd, C.N.; Ferro, A. Mechanisms of aspirin resistance. Pharmacol. Ther. 2014, 141, 69-78.

13. Santilli, F.; Paloscia, L.; Liani, R.; di Nicola, M.; di Marco, M.; Lattanzio, S.; la Barba, S.; Pascale, S.; Mascellanti, M.; Davì, G. Circulating Myeloid-Related Protein-8/14 is Related to Thromboxane-Dependent Platelet Activation in Patients With Acute Coronary Syndrome, With and Without Ongoing Low-Dose Aspirin Treatment. J. Am. Heart Assoc. 2014, 3, e000903. 
14. Vitale, P.; Tacconelli, S.; Perrone, M.G.; Malerba, P.; Simone, L.; Scilimati, A.; Lavecchia, A.; Dovizio, M.; Marcantoni, E.; Bruno, A.Others Synthesis, pharmacological characterization, and docking analysis of a novel family of diarylisoxazoles as highly selective cyclooxygenase-1 (COX-1) inhibitors. J. Med. Chem. 2013, 56, 4277-4299.

15. Roche, V.F. A receptor-grounded approach to teaching nonsteroidal antiinflammatory drug chemistry and structure-activity relationships. Am. J. Pharm. Educ. 2009, 73, 143.

16. Khamdang, S.; Takeda, M.; Noshiro, R.; Narikawa, S.; Enomoto, A.; Anzai, N.; Piyachaturawat, P.; Endou, H. Interactions of human organic anion transporters and human organic cation transporters with nonsteroidal anti-inflammatory drugs. J. Pharmacol. Exp. Ther. 2002, 303, 534-539.

17. Hagos, Y.; Wolff, N.A. Assessment of the role of renal organic anion transporters in drug-induced nephrotoxicity. Toxins 2010, 2, 2055-2082.

18. Liedtke, A.J.; Crews, B.C.; Daniel, C.M.; Blobaum, A.L.; Kingsley, P.J.; Ghebreselasie, K.; Marnett, L.J. Cyclooxygenase-1-selective inhibitors based on the $(E)-2$ '-des-methyl-sulindac sulfide scaffold. J. Med. Chem. 2012, 55, 2287-2300.

19. Li, J.; Tan, Z.; Tang, S.; Hewlett, I.; Pang, R.; He, M.; He, S.; Tian, B.; Chen, K.; Yang, M. Discovery of dual inhibitors targeting both HIV-1 capsid and human cyclophilin A to inhibit the assembly and uncoating of the viral capsid. Bioorg. Med. Chem. 2009, 17, 3177-3188.

20. Li, H.-Q.; Lv, P.-C.; Yan, T.; Zhu, H.-L. Urea derivatives as anticancer agents. Anticancer Agents Med. Chem. 2009, 9, 471-480.

21. Zhang, H.; Zhang, Y.; Wu, G.; Zhou, J.; Huang, W.; Hu, X. Synthesis and biological evaluation of sulfonylurea and thiourea derivatives substituted with benzenesulfonamide groups as potential hypoglycemic agents. Bioorg. Med. Chem. Lett. 2009, 19, 1740-1744.

22. Perlovich, G.L.; Proshin, A.N.; Volkova, T.V.; Kurkov, S.V.; Grigoriev, V.V.; Petrova, L.N.; Bachurin, S.O. Novel isothiourea derivatives as potent neuroprotectors and cognition enhancers: Synthesis, biological and physicochemical properties. J. Med. Chem. 2009, 52, 1845-1852.

23. Kang, I.-J.; Wang, L.-W.; Lee, C.-C.; Lee, Y.-C.; Chao, Y.-S.; Hsu, T.-A.; Chern, J.-H. Design, synthesis, and anti-HCV activity of thiourea compounds. Bioorg. Med. Chem. Lett. 2009, 19, 1950-1955.

24. Kazimierczuk, Z.; Chalimoniuk, M.; Laudy, A.E.; Moo-Puc, R.; Cedillo-Rivera, R.; Starosciak, B.J.; Chrapusta, S.J. Synthesis and antimicrobial and nitric oxide synthase inhibitory activities of novel isothiourea derivatives. Arch. Pharm. Res. 2010, 33, 821-830.

25. Michaux, C.; de Leval, X.; Julémont, F.; Dogné, J.-M.; Pirotte, B.; Durant, F. Structure-based pharmacophore of COX-2 selective inhibitors and identification of original lead compounds from 3D database searching method. Eur. J. Med. Chem. 2006, 41, 1446-1455.

26. Ventosa-Andrés, P.; Valdivielso, Á.M.; Pappos, I.; García-López, M.T.; Tsopanoglou, N.E.; Herranz, R. Design, synthesis and biological evaluation of new peptide-based ureas and thioureas as potential antagonists of the thrombin receptor PAR1. Eur. J. Med. Chem. 2012, 58, 98-111.

27. Dutta, A.K.; Okada, Y.; Sabirov, R.Z. Regulation of an ATP-conductive large-conductance anion channel and swelling-induced ATP release by arachidonic acid. J. Physiol. 2002, 542, 803-816.

28. Xiang, L.; Dearman, J.; Abram, S.R.; Carter, C.; Hester, R.L. Insulin resistance and impaired functional vasodilation in obese Zucker rats. Am. J. Physiol.-Heart Circ. Physiol. 2008, 294, H1658-H1666. 
29. Sathler, P.C.; Santana, M.; Lourenço, A.L.; Rodrigues, C.R.; Abreu, P.; Cabral, L.M.; Castro, H.C. Human thromboxane synthase: Comparative modeling and docking evaluation with the competitive inhibitors Dazoxiben and Ozagrel. J. Enzym. Inhib. Med. Chem. 2013, 29, 527-531.

30. Cathcart, M.C.; Gately, K.; Cummins, R.; Drakeford, C.; Kay, E.W.; O’Byrne, K.J.; Pidgeon, G.P. Thromboxane synthase expression and correlation with VEGF and angiogenesis in non-small cell lung cancer. Biochim. Biophys. Acta BBA-Mol. Basis Dis. 2014, 1842, 747-755.

31. Sun, J.; Zhong, W.; Gu, Y.; Groome, L.J.; Wang, Y. 1, $25(\mathrm{OH})<\operatorname{sub}>2</$ sub $>\mathrm{D}<\mathrm{sub}>3</$ sub $>$ suppresses COX-2 up-regulation and thromboxane production in placental trophoblast cells in response to hypoxic stimulation. Placenta 2014, 35, 143-145.

32. Cuendet, M.; Mesecar, A.D.; DeWitt, D.L.; Pezzuto, J.M. An ELISA method to measure inhibition of the COX enzymes. Nat. Protoc. 2006, 1, 1915-1921.

33. Uno, K.; Iuchi, Y.; Fujii, J.; Sugata, H.; Iijima, K.; Kato, K.; Shimosegawa, T.; Yoshimura, T. In vivo study on cross talk between inducible nitric-oxide synthase and cyclooxygenase in rat gastric mucosa: Effect of cyclooxygenase activity on nitric oxide production. J. Pharmacol. Exp. Ther. 2004, 309, 995-1002.

34. Sharma, N.P.; Dong, L.; Yuan, C.; Noon, K.R.; Smith, W.L. Asymmetric acetylation of the cyclooxygenase-2 homodimer by aspirin and its effects on the oxygenation of arachidonic, eicosapentaenoic, and docosahexaenoic acids. Mol. Pharmacol. 2010, 77, 979-986.

35. Liu, Y.; Jennings, N.L.; Dart, A.M.; Du, X.-J. Standardizing a simpler, more sensitive and accurate tail bleeding assay in mice. World J. Exp. Med .2012, 2, 30-36.

36. Sadilkova, L.; Paluch, Z.; Mottlova, J.; Bednar, F.; Alusik, S. The purification step is not crucial in EIA measurements of thromboxane B2 and 11-dehydrothromboxane B2 in human plasma. Clin. Lab. 2012, 58, 177-183.

37. Jeng, J.-H.; Chen, S.-Y.; Liao, C.-H.; Tung, Y.-Y.; Lin, B.-R.; Hahn, L.-J.; Chang, M.-C. Modulation of platelet aggregation by areca nut and betel leaf ingredients: Roles of reactive oxygen species and cyclooxygenase. Free Radic. Biol. Med. 2002, 32, 860-871.

38. Aziz, S.M.; Pauly, T.H.; Gillespie, M.N. Intrinsic microbicidal activity and pulmonary hypertension in isolated newborn piglet lungs. Pediatr. Res. 1993, 34, 32-37.

39. Kaufman, R.P., Jr.; Klausner, J.M.; Anner, H.; Feingold, H.; Kobzik, L.; Valeri, C.R.; Shepro, D.; Hechtman, H.B. Inhibition of thromboxane (Tx) synthesis by free radical scavengers. J. Trauma-Inj. Infect. Crit. Care 1988, 28, 458-464.

40. Araujo, M.C.P.; Antunes, L.M.; Takahashi, C.S. Protective effect of thiourea, a hydroxyl-radical scavenger, on curcumin-induced chromosomal aberrations in an in vitro mammalian cell system. Teratog. Carcinog. Mutagen. 2001, 21, 175-180.

41. Scholz, M.; Ulbrich, H.K.; Dannhardt, G. Investigations concerning the COX/5-LOX inhibiting and hydroxyl radical scavenging potencies of novel 4, 5-diaryl isoselenazoles. Eur. J. Med. Chem. 2008, $43,1152-1159$.

42. Chao, W.-C.; Lu, J.-F.; Wang, J.-S.; Yang, H.-C.; Pan, T.-A.; Chou, S.C.-W.; Wang, L.-H.; Chou, P.-T. Probing Ligand Binding to Thromboxane Synthase. Biochemistry (Mosc.) 2013, 52, 1113-1121.

43. Kontogiorgis, C.; Hadjipavlou-Litina, D. Thromboxane synthase inhibitors and thromboxane A2 receptor antagonists: A quantitative structure activity relationships (QSARs) analysis. Curr. Med. Chem. 2010, 17, 3162-3214. 
44. Sathler, P.C.; Lourenço, A.L.; Rodrigues, C.R.; da Silva, L.C.R.P.; Cabral, L.M.; Jordão, A.K.; Cunha, A.C.; Vieira, M.C.B.; Ferreira, V.F.; Carvalho-Pinto, C.E.; et al. In vitro and in vivo analysis of the antithrombotic and toxicological profile of new antiplatelets $\mathrm{N}$-acylhydrazone derivatives and development of nanosystems: Determination of novel NAH derivatives antiplatelet and nanotechnological approach. Thromb. Res. 2014, 134, 376-383.

45. Curvers, J.; van de Kerkhof, D.; Stroobants, A.K.; van Den Dool, E.-J.; Scharnhorst, V. Measuring Direct Thrombin Inhibitors With Routine and Dedicated Coagulation Assays Which Assay Is Helpful? Am. J. Clin. Pathol. 2012, 138, 551-558.

46. Raju, N.C.; Eikelboom, J.W.; Hirsh, J. Platelet ADP-receptor antagonists for cardiovascular disease: Past, present and future. Nat. Clin. Pract. Cardiovasc. Med.2008, 5, 766-780.

47. Sashidhara, K.V.; Palnati, G.R.; Avula, S.R.; Singh, S.; Jain, M.; Dikshit, M. Synthesis and evaluation of anti-thrombotic activity of benzocoumarin amide derivatives. Bioorg. Med. Chem. Lett. 2012, 22, 3115-3121.

48. Fischer, D.; Li, Y.; Ahlemeyer, B.; Krieglstein, J.; Kissel, T. In vitro cytotoxicity testing of polycations: Influence of polymer structure on cell viability and hemolysis. Biomaterials 2003, 24, 1121-1131.

49. Ochoa, A.L.; Tempesti, T.C.; Spesia, M.B.; Milanesio, M.E.; Durantini, E.N. Synthesis and photodynamic properties of adamantylethoxy $\mathrm{Zn}(\mathrm{II})$ phthalocyanine derivatives in different media and in human red blood cells. Eur. J. Med. Chem. 2012, 50, 280-287.

50. Ilker, M.F.; Nüsslein, K.; Tew, G.N.; Coughlin, E.B. Tuning the Hemolytic and Antibacterial Activities of Amphiphilic Polynorbornene Derivatives. J. Am. Chem. Soc. 2004, 126, 15870-15875.

51. Pennell, A.M.K.; Aggen, J.B.; Sen, S.; Chen, W.; Xu, Y.; Sullivan, E.; Li, L.; Greenman, K.; Charvat, T.; Hansen, D.; et al. 1-(4-Phenylpiperazin-1-yl)-2-(1H-pyrazol-1-yl)ethanones as novel CCR1 antagonists. Bioorg. Med. Chem. Lett. 2013, 23, 1228-1231.

52. Hajisharifi, Z.; Piryaiee, M.; Mohammad Beigi, M.; Behbahani, M.; Mohabatkar, H. Predicting anticancer peptides with Chou's pseudo amino acid composition and investigating their mutagenicity via Ames test. J. Theor. Biol. 2014, 341, 34-40.

53. Quillardet, P.; Hofnung, M. The SOS chromotest, a colorimetric bacterial assay for genotoxins: Procedures. Mutat. Res. Mutagen. Relat. Subj. 1985, 147, 65-78.

54. Heler, R.; Bell, J.K.; Boland, L.M. Homology model and targeted mutagenesis identify critical residues for arachidonic acid inhibition of Kv4 channels. Channels 2013, 7, 74-84.

55. Reyes, J.J.; de La Cruz, J.P.; Muñoz-Marin, J.; Guerrero, A.; Lopez-Villodres, J.A.; Madrona, A.; Espartero, J.L.; Gonzalez-Correa, J.A. Antiplatelet effect of new lipophilic hydroxytyrosol alkyl ether derivatives in human blood. Eur. J. Nutr. 2013, 52, 591-599.

56. Aldrovandi, M.; Hammond, V.J.; Podmore, H.; Hornshaw, M.; Clark, S.R.; Marnett, L.J.; Slatter, D.A.; Murphy, R.C.; Collins, P.W.; O’Donnell, V.B. Human platelets generate phospholipid-esterified prostaglandins via cyclooxygenase-1 that are inhibited by low dose aspirin supplementation. J. Lipid Res. 2013, 54, 3085-3097.

57. Jedlitschky, G.; Greinacher, A.; Kroemer, H.K. Transporters in human platelets: Physiologic function and impact for pharmacotherapy. Blood 2012, 119, 3394-3402.

58. Malkowski, M.G.; Ginell, S.L.; Smith, W.L.; Garavito, R.M. The productive conformation of arachidonic acid bound to prostaglandin synthase. Science 2000, 289, 1933-1937. 
59. Limongelli, V.; Bonomi, M.; Marinelli, L.; Gervasio, F.L.; Cavalli, A.; Novellino, E.; Parrinello, M. Molecular basis of cyclooxygenase enzymes (COXs) selective inhibition. Proc. Natl. Acad. Sci. USA 2010, 107, 5411-5416.

60. Furse, K.E.; Pratt, D.A.; Porter, N.A.; Lybrand, T.P. Molecular dynamics simulations of arachidonic acid complexes with COX-1 and COX-2: Insights into equilibrium behavior. Biochemistry (Mosc.) 2006, 45, 3189-3205.

61. Kalgutkar, A.S.; Marnett, A.B.; Crews, B.C.; Remmel, R.P.; Marnett, L.J. Ester and amide derivatives of the nonsteroidal antiinflammatory drug, indomethacin, as selective cyclooxygenase-2 inhibitors. J. Med. Chem. 2000, 43, 2860-2870.

62. Selinsky, B.S.; Gupta, K.; Sharkey, C.T.; Loll, P.J. Structural analysis of NSAID binding by prostaglandin $\mathrm{H} 2$ synthase: Time-dependent and time-independent inhibitors elicit identical enzyme conformations. Biochemistry (Mosc.) 2001, 40, 5172-5180.

63. Duggan, K.C.; Walters, M.J.; Musee, J.; Harp, J.M.; Kiefer, J.R.; Oates, J.A.; Marnett, L.J. Molecular basis for cyclooxygenase inhibition by the non-steroidal anti-inflammatory drug naproxen. J. Biol. Chem. 2010, 285, 34950-34959.

64. Blobaum, A.L.; Marnett, L.J. Structural and functional basis of cyclooxygenase inhibition. J. Med. Chem. 2007, 50, 1425-1441.

65. Saxena, A.; Balaramnavar, V.M.; Hohlfeld, T.; Saxena, A.K. Drug/drug interaction of common NSAIDs with antiplatelet effect of aspirin in human platelets. Eur. J. Pharmacol. 2013, 721, 215-224.

66. Hoffmann, I.; Hamberg, M.; Lindh, R.; Oliw, E.H. Novel insights into cyclooxygenases, linoleate diol synthases, and lipoxygenases from deuterium kinetic isotope effects and oxidation of substrate analogs. Biochim. Biophys. Acta 2012, 1821, 1508-1517.

67. Wu, G.; Tsai, A.-L.; Kulmacz, R.J. Cyclooxygenase Competitive Inhibitors Alter Tyrosyl Radical Dynamics in Prostaglandin H Synthase-2. Biochemistry (Mosc.) 2009, 48, 11902-11911.

68. Alawode, O.E.; Robinson, C.; Rayat, S. Clean Photodecomposition of 1-Methyl-4-phenyl-1Htetrazole-5(4H)-thiones to Carbodiimides Proceeds via a Biradical. J. Org. Chem. 2011, 76, 216-222.

69. Natarajan, A.; Guo, Y.; Arthanari, H.; Wagner, G.; Halperin, J.A.; Chorev, M. Synthetic Studies toward Aryl-(4-aryl-4H-[1,2,4]triazole-3-yl)-amine from 1,3-Diarylthiourea as Urea Mimetics. J. Org. Chem. 2005, 70, 6362-6368.

70. Bernacki, A.L.; Zhu, L.; Hennings, D.D. A Selective and Convenient Method for the Synthesis of 2-Phenylaminothiazolines. Org. Lett. 2010, 12, 5526-5529.

71. Smith, P.A.; Leon, E. The Thermal Breakdown of Diaryltetrazoles. J. Am. Chem. Soc. 1958, 80, 4647-4654.

72. De Sequeira Aguiar, L.C.; Viana, G.M.; dos Santos Romualdo, M.V.; Costa, M.V.; Bonato, B.S. A Simple and Green Procedure for the Synthesis of $N$-Benzylthioureas. Lett. Org. Chem. 2011, 8 , 540-544.

73. Maddani, M.; Prabhu, K.R. A convenient method for the synthesis of substituted thioureas. Tetrahedron Lett. 2007, 48, 7151-7154.

74. Maddani, M.R.; Prabhu, K.R. A Concise Synthesis of Substituted Thiourea Derivatives in Aqueous Medium. J. Org. Chem. 2010, 75, 2327-2332.

75. Born, G.V.R.; Cross, M.J. The aggregation of blood platelets. J. Physiol. 1963, 168, 178-195. 
76. Cunha, A.C.; Figueiredo, J.M.; Tributino, J.L.; Miranda, A.L.; Castro, H.C.; Zingali, R.B.; Fraga, C.A.; de Souza, M.C.B.; Ferreira, V.F.; Barreiro, E.J. Antiplatelet properties of novel $N$-substitutedphenyl-1,2,3-triazole-4-acylhydrazone derivatives. Bioorg. Med. Chem. 2003, 11, 2051-2059.

77. Jordão, A.K.; Ferreira, V.F.; Lima, E.S.; de Souza, M.C.B.V.; Carlos, E.C.L.; Castro, H.C.; Geraldo, R.B.; Rodrigues, C.R.; Almeida, M.C.B.; Cunha, A.C. Synthesis, antiplatelet and in silico evaluations of novel $\mathrm{N}$-substituted-phenylamino-5-methyl-1H-1,2,3-triazole-4-carbohydrazides. Bioorg. Med. Chem. 2009, 17, 3713-3719.

78. Faye, E.; Drouet, L.; de Raucourt, E.; Green, A.; Bal-dit -Sollier, C.; Boudaoud, L.; Corcos, O.; Bergmann, J.-F.; Joly, F.; Lloret-Linares, C. Absorption and Efficacy of Acetylsalicylic Acid in Patients With Short Bowel Syndrome. Ann. Pharmacother. 2014, 48, 705-710.

79. Parnham, M.J.; Wetzig, H. Toxicity screening of liposomes. Chem. Phys. Lipids 1993, 64, 263-274.

80. Bauer, M.; Lautenschlaeger, C.; Kempe, K.; Tauhardt, L.; Schubert, U.S.; Fischer, D. Poly (2-ethyl2-oxazoline) as Alternative for the Stealth Polymer Poly (ethylene glycol): Comparison of in vitro Cytotoxicity and Hemocompatibility. Macromol. Biosci. 2012, 12, 986-998.

81. Maron, D.M.; Ames, B.N. Revised methods for the Salmonella mutagenicity test. Mutat. Res. Mutagen. Relat. Subj. 1983, 113, 173-215.

82. Valencia, A.; Prous, J.; Mora, O.; Sadrieh, N.; Valerio, J. A novel QSAR model of Salmonella mutagenicity and its application in the safety assessment of drug impurities. Toxicol. Appl. Pharmacol. 2013, 273, 427-434.

83. Menegatti, R.; Cunha, A.C.; Ferreira, V.F.; Perreira, E.F.; El-Nabawi, A.; Eldefrawi, A.T.; Albuquerque, E.X.; Neves, G.; Rates, S.M.; Fraga, C.A.; et al. Design, synthesis and pharmacological profile of novel dopamine D2 receptor ligands. Bioorg. Med. Chem. 2003, 11, 4807-4813.

84. Cosconati, S.; Forli, S.; Perryman, A.L.; Harris, R.; Goodsell, D.S.; Olson, A.J. Virtual screening with AutoDock: Theory and practice. Expert Opin. Drug Discov. 2010, 5, 597-607.

85. Santos, C.B.R.; Lobato, C.C.; Braga, F.S.; Morais, S.S.S.; Santos, C.F.; Fernandes, C.P.; Brasil, D.S.B.; Hage-Melim, L.I.S.; Macêdo, W.J.C.; Carvalho, J.C.T. Application of Hartree-Fock Method for Modeling of Bioactive Molecules Using SAR and QSPR. Comput. Mol. Biosci. 2014, 4, 1-24.

86. Gervasio, F.L.; Laio, A.; Parrinello, M. Flexible docking in solution using metadynamics. J. Am. Chem. Soc. 2005, 127, 2600-2607.

87. Bourguignon, S.C.; Cavalcanti, D.F.; de Souza, A.M.; Castro, H.C.; Rodrigues, C.R.; Santos, D.O.;Albuquerque, M.G.; da Silva, G.G.; da Silva, F.C.; Ferreira, V.F.Trypanosoma cruzi: Insights into naphthoquinone effects on growth and proteinase activity. Exp. Parasitol. 2011, 127, 160-166.

Sample Availability: Samples of the compounds $\mathbf{3 a - q}$ are available from the authors via INCT-IF (http://www.inct-if.com.br/portal/).

(C) 2015 by the authors; licensee MDPI, Basel, Switzerland. This article is an open access article distributed under the terms and conditions of the Creative Commons Attribution license (http://creativecommons.org/licenses/by/4.0/). 